\title{
العلاقة بين بعض القضايا المعاصرة وانتماء الثباب الريفي للمجتمع المحلي بمحافظة الغربية
}

ليلي مراد محمد الخلواني، عبير عبد الستار محمد علام، هدي محمد إبراهيم الليثي

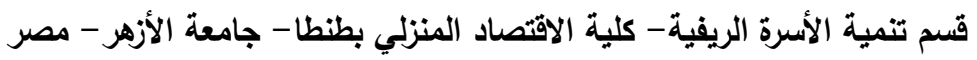

Received: Mar. 7, 2021

Accepted: Mar. 20, 2021

ملخص البحث

يستهلف البحث بصفة رئيسية التعرف على طبيعة العلاقة بين بعض القضـايا المعاصرة وانتمـاء الثباب الريفي

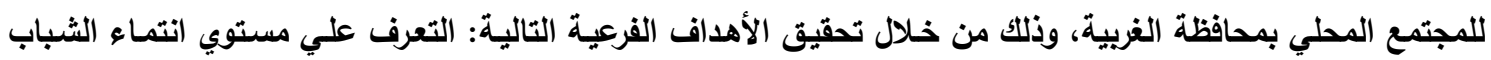

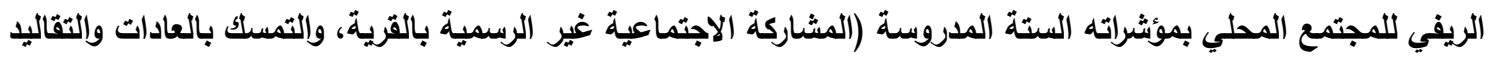

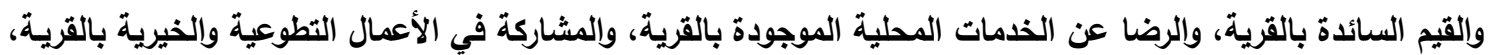

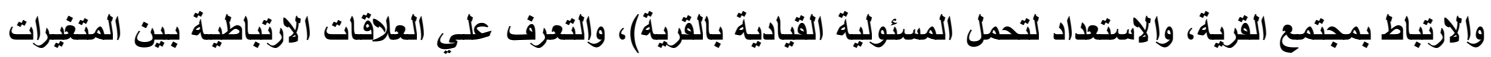

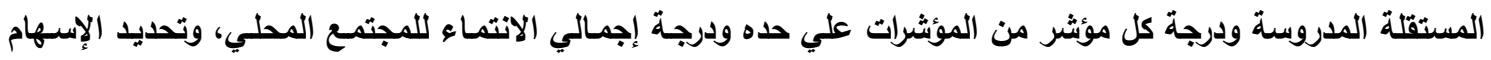

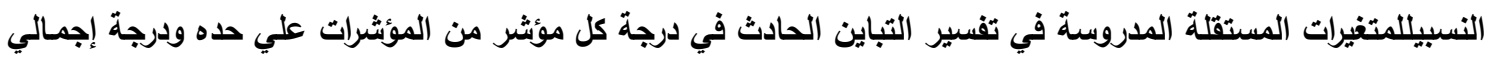
الانتماء للمجتمع المحلي. أجري البحث علي عينة عثوائية قوامها 375 شاب في الفئة العمرية من (20 - 35) سنة فئة من القري الثلاثـة المختارة للاراسـة وهي (فيثـا سليم- خرسيت - كفر سبطاس). جمعت البيانات بالمقابلة الثخصية

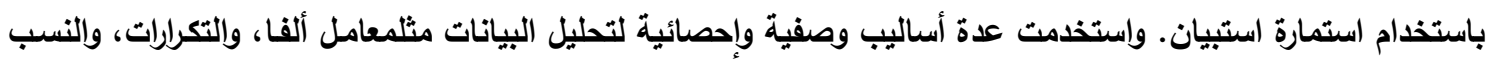

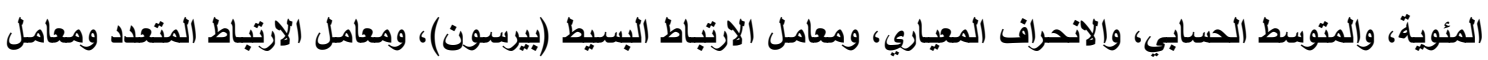
الانحدار الجزئي المعياري. وقد تلخصت أبرز النتائج فيما يلي: أن مستوي كل من التمكك بالعادات والتقاليا والقيم السائدة

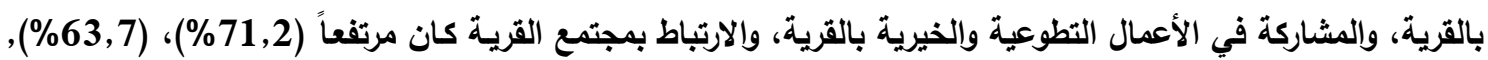

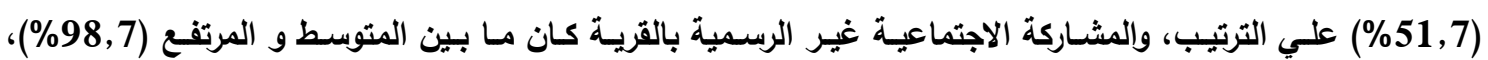

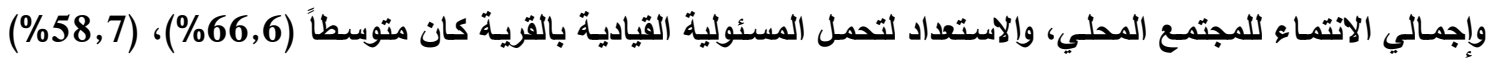
علي الترتيب، وتقارب مستوي الرضا عن الخدمات المحلية الموجودة بالقرية في الفئات الثلاثة. تبين وجود علاقة ارتباطية طردية ومعنوية بين الدافعية للإنجاز، وقضية استخدام وسائل التواصل الاجتماعي وبين درجة إجمالي الانتماء للمجتمع التعادي

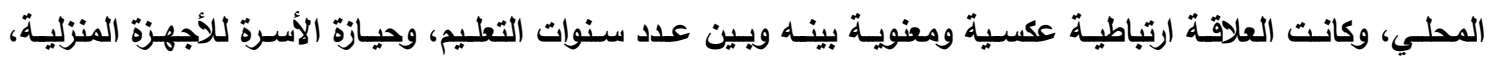

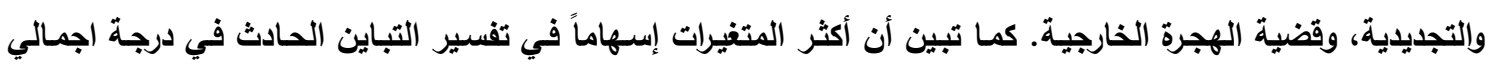

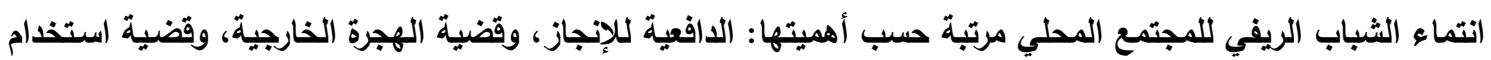
وسائل التواصل الاجتماعي، والتجديدية، وقضية ارتفاع تكاليف الزواج، وتفسر نحو (26,8\%) من التباين الحادث.وكانئ

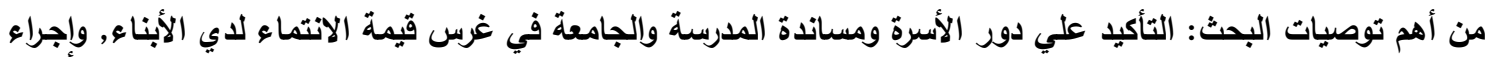
المزيد من الدراسات علي موضوع الانتماء عامة وخاصة للمجتمع المحلي لدي الثباب عامة والريفي خاصة. الكلمـات الاسترشــادية: الثـباب، الانتمـاء، الخصخصـة، اللاعم، تكـاليف الزواج، وسـائل التواصـل الاجتمـاعي، الهجرة

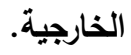


منهم، ويرتضون وجوده معهم، (محمد وقطاني، 2010،

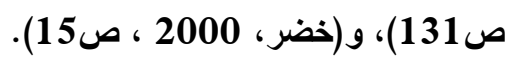

والثباب والفتيات أولى فئات المجتمع بالانتماء إليه،

إذ أنهم نصف الحاضر وكل المستقبل وأمل المجتمع في غد أفضل، وشعور الثباب بالحب نحو مجتمعه يزداد كلما شعر بأن المجتمع يقام لله الرعاية بمختلف أشكالها الصحية والنفسية والاجتماعيـة والاقتصـادية والتعليميـة، ويـوفر لـه الحيـاة الكريمـة وحريـة التعبير عن الـات،

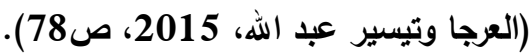

والملاحظ للحيـاة النفسية والاجتماعيـة التي يحياهـا الثباب تؤكلد مـا يعانونهه من اغتراب وخلل واضطراب ، وفي عصر التطور التقنسي والانفجـار المعرفي نجد أن الأمور تسير في طريق إبعاد الفرد عن انتمائه ووطنيته أكثر فأكثر، ويبدو ذلك واضحا من خلال الميل المتنافي

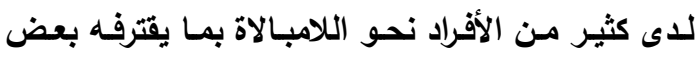

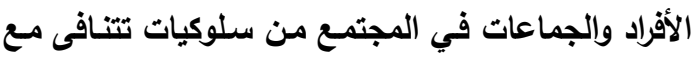
قـيم وعـادات وتقاليـــ المجتمـع، (ســليمان، 2013،

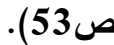

ويلعب الانتمـاء دوراً مههـاً في تحديد علاقة الأفراد

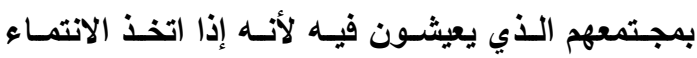
صورة غير طبيعية فإن ذلك يدفع الأفراد القيام بسلوكيات

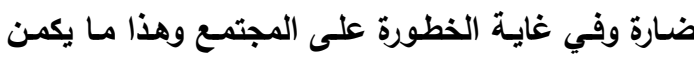
وراء ضعف الانتماء.

ويواجه المجتمع المصري في الوقت الراهن تحديات

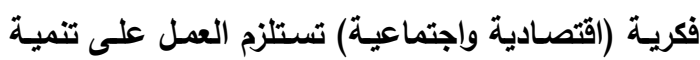
وعي الثباب بمبادئ المواطنة والانتماء وتمثيله سلوكا

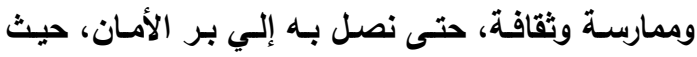

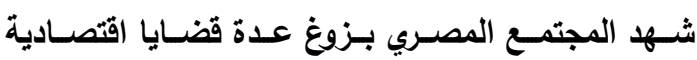

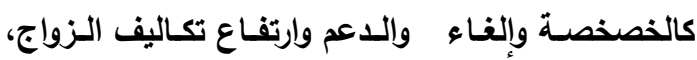
وأخرى اجتماعية كاستخدام وسـائل التواصل الاجتمـاعي الحايثة والهجـرة الخارجيـة، وتلـك القضـايا لهـا تأثيرهـا الحيوي على المجتمـع بكل قطاعاته وفئاتهـ بصفة عامـة
المقدمة والمشكلة البحثية الثباب عماد كل مجتمع، وركيزة كل دولة، وأمل كل أمسـة وقلبهـا النـابض وغنـوان نهضـتها وارتقاؤهـا، فهـ

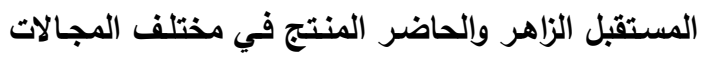
والأنشطة، ويشكلون بكل فئاتهم نحو 45\% من السكان، ومسن هنـا كـان مسن الضـروري تثقيـف الثـباب وتنميــة

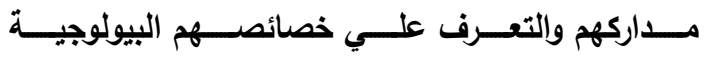

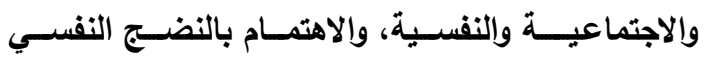
والاجتمـاعي ودراسـة احتياجـاتهم، والاهتمـام بقضــاياهم

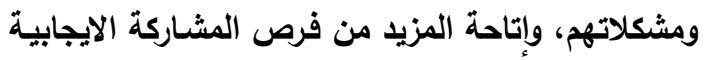

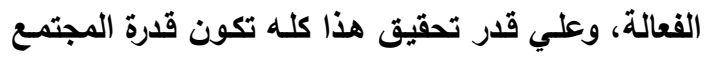
علي استثمار أغلي ثرواته وتوجيه طاقة الثباب بصورة

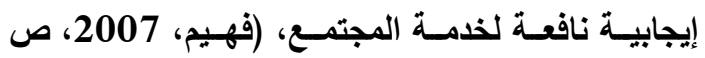
ص9: 10 10). يُعد الانتماء قيمة من أهم القيم التي كانت ولا تزال

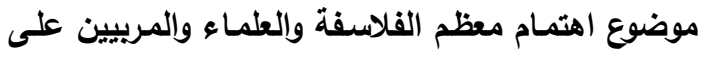

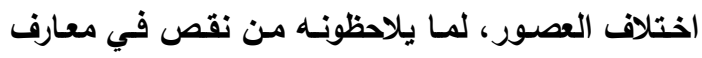

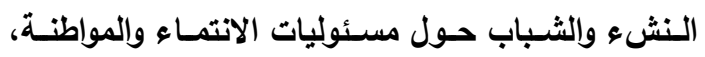
وعدم الوعي بالحقوق والواجبات والمسئوليات المدنية في

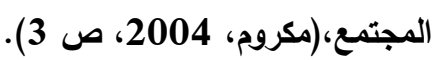
والحاجـة إلـي الانتمـاء من الحاجـات الأساسية التـي

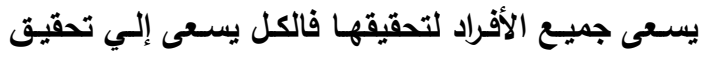

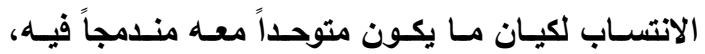
باعتباره عضواً مقبولاً لـه شرف الانتساب إليه، وتحرص فلان

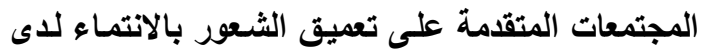

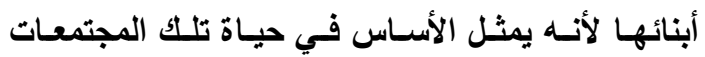

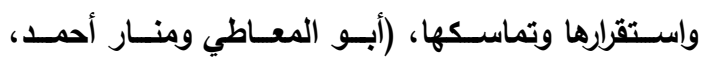
2018، ص567). كمـا يعتبر الانتمـاء بمثابـة اتجـاه يحركـه دافـع قـوي

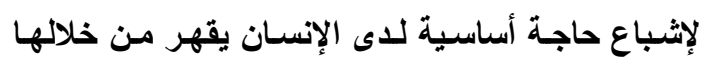

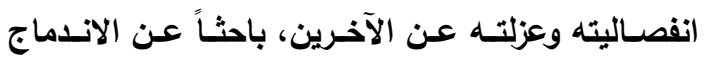

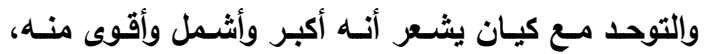
ويبحث عن الأمان لتحقيق ذاته مـع آخرين يكون مقبولاً 


$$
\text { أ- الإطار المفهومي: }
$$

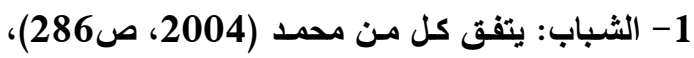

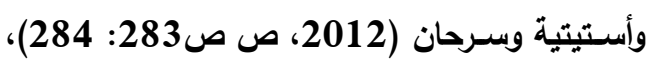

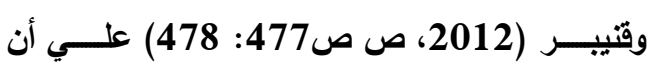

مفهوم الثباب يتسع للعديد من الاتجاهات التي من صن

$$
\text { أبرزها: }
$$

- الاتجاه البيولوجي: الذي يؤكل على الحتمية البيولوجية

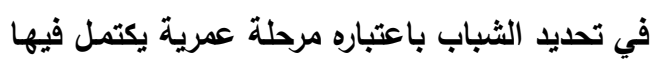
نضجه الإنسان العضوي الفيزيقي والعقلي النفسي.

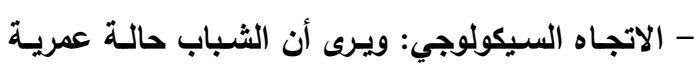

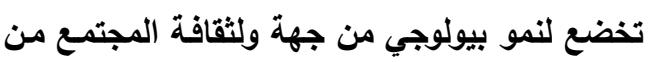

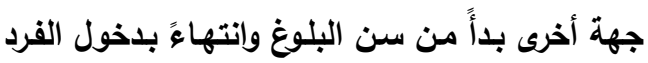

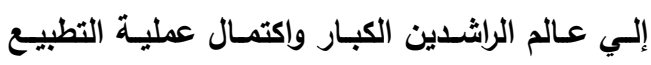
الاجتماعي. - الاتجـاه السسيولوجي: وينظر إلـي الثـباب باعتبـاره حقيقة اجتماعية وليس ظاهرة بيولوجية فقط، بمعنى

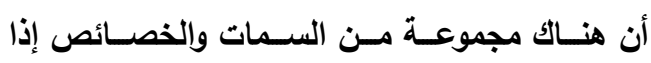

توافرت في فئة من السكان كانت هذه الفئة شباباً. - الاتجاه التكاملي: ويرى الثباب باعتباره حالة أو ظاهرة

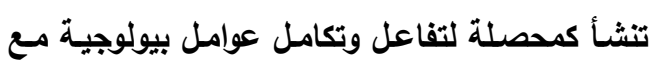
خصائص نفسية في سياق عناصر ومحددات ثقافية

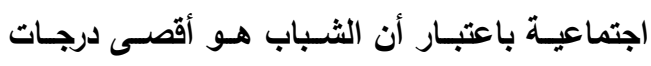
الحيوية بيولوجياً وفيزيقياً وعقلياً ونفسياً واجتماعياً.

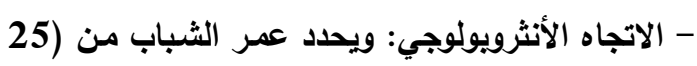

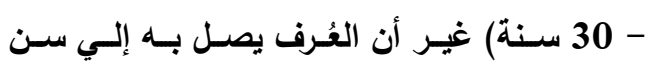

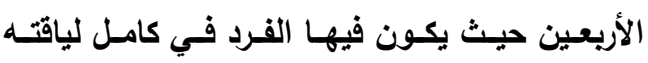
الجسمانية ونضجه العقلي.

- الاتجاه الايموجرافي: استند علماء السكان إلبي معيار

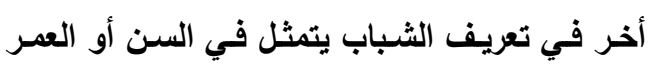

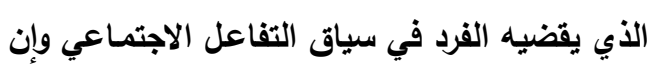
اختلفوا فيما بينهم في تحديد بداية ونهاية هذا السن.

2- الانتماء: هو الانتساب أولاً للأسرة والقبيلة والمدينة

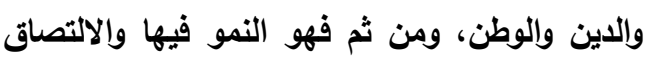

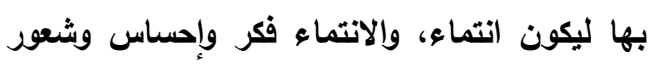

ولا شكك أن هذه القضـايا المثارة على السـاحة في المجتمع المصري والمصاحبة للتغيرات والتطورات العالمية

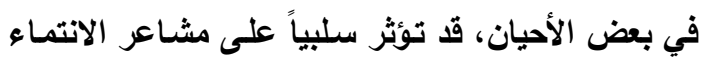
لاى أفراد المجتمع خاصة الثباب باعتبارهم الفئة الأكثر حساسية للأوضاع والتغيرات المجتمعية، ونتيجة لأهمية هذه الفئة في المجتمع، ونظراً لما يثكله ضعف لاعن الانتماء للدى الثباب مـن خطورة على المجتمـع المصري ونظراً

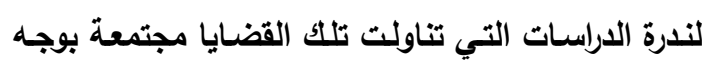

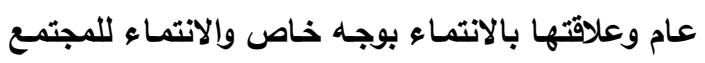
المحلي علي الأخص، تكمن مشكلة البحث الحالية. أهداف البحث يستهاف البحث بصفة رئيسية التعرف على طبيعة

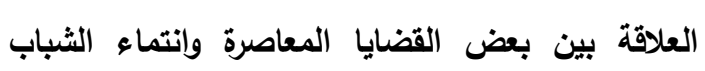

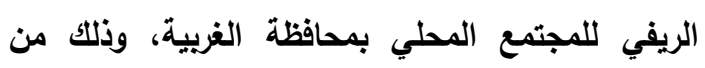
خلال تحقيق الأهداف الفرعية التالية: 1- التعرف علي مستوي انتماء الثباب الريفي للمجتمع الإئ

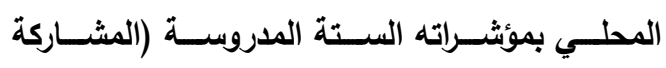
الاجتماعية غير الرسمية بالقرية، والتمسك بالعادات

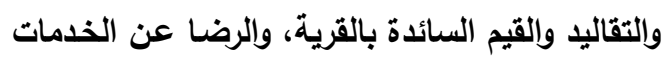
المحليـة الموجـودة بالقريـة، والمشـاركة في الأعمـال

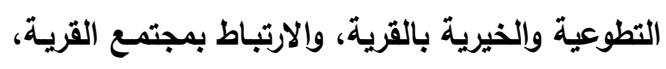
والاستعداد لتحمل المسئولية القيادية بالقرية). 2- التعـرف علـي العلاقــات الارتباطيـة بـين المتغيـرات

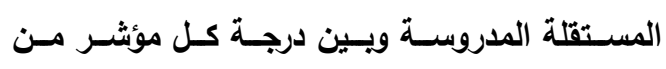
المؤثرات الستة علـي حده ودرجـة إجمالي انتمـاء الشباب الريفي للمجتمع المحلي.

3- تحديد الإسهام النسبي للمتغيرات المستقلة المدروسة

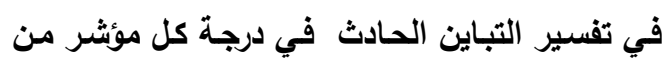

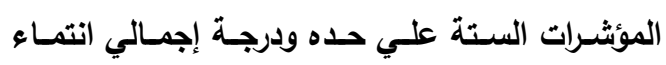
الثباب الريفي للمجتمع المحلي. الإطار النظري والاستعراض المرجعي أولاً: الإطار النظري 
الأعمـال التطوعية والخيريـة والمناسبات المختلفة. وتُعد تنمية روح الانتماء للدى الثباب من أهم سبل مواجهة

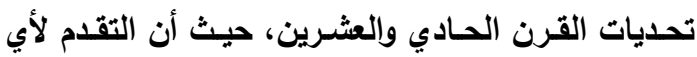
مجتمع في ظل تحديات هذا القرن ومستحدثاته تصنعه عقول وسواعد أبناؤه. والثـعور بالانتمـاء يتطلب الثـعور بالراحـة والأمسان الاقتصادي والاجتماعي والسياسي في الوطن حيث تؤدي

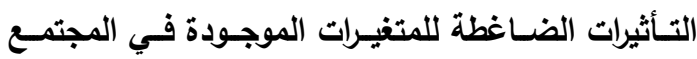
والتي منها نقص فرص العمل وتراجع قيمـة الثـهادات

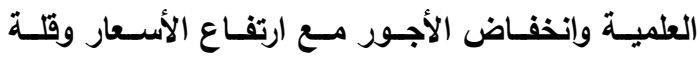

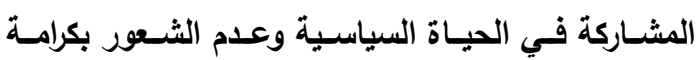
الإنسان وإحساسه بالقهر وقلة الثقة فى مؤسسات الدولة

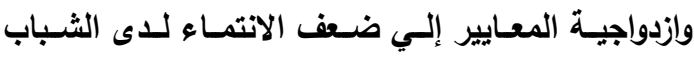
وعندها تتثكل مشاعر الاغتراب ومـا يصاحبه من ظاهر السلبية واللامبالاة نحو المجتمع، (أبو المعاطي ومنـار

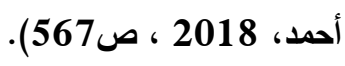

3- الخصخصة: هي انتقال الوحدات الإنتاجية السلعية التهات

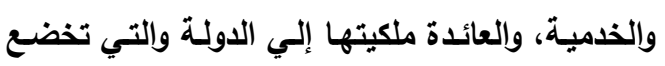

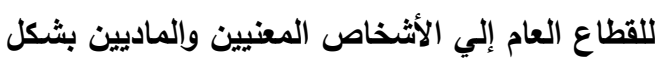

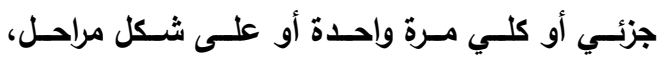
بأساليب مباشرة أو غير مباشرة، ويشكل مخطط ومهيأ لـه بظروف تمهيديـة، ممـا يـؤدي إلـي إعـادة هيكلة فئة الوحـدات الإنتاجيـة المعنيـة، وتغييـر قـوى الإنتـاج

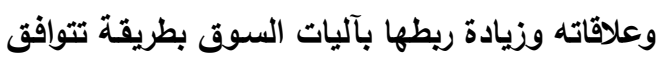

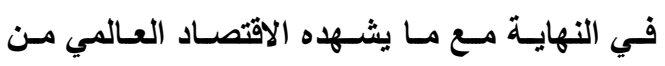

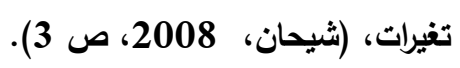

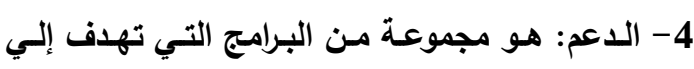

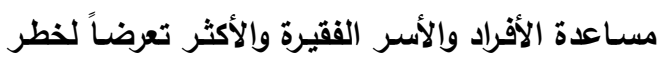

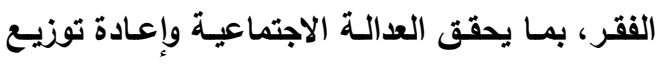

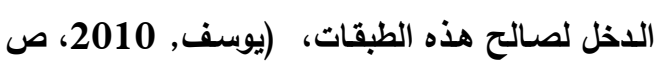

5- تكاليف الزواج: هي مجموعة من الأمور التي تتكلف مادياً ويتم الاتفاق عليها من أجل الزواج لتنفيذها عند من الأدور التي

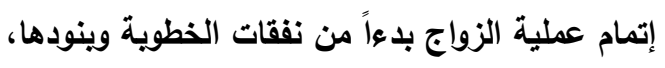

داخلي تجسده الجوارح يتعدد ويتتوع والكنه بكل الأحوال يجب ألا يتعدى حدود الوطن، بمعنى أنه

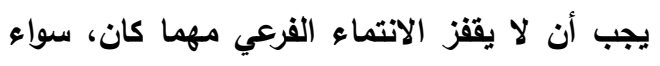
للأسرة أو القبيلة أو المنطقة أو الحزب أو المذهب ألهب

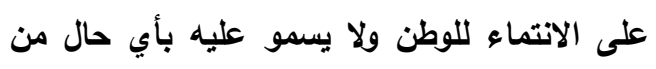

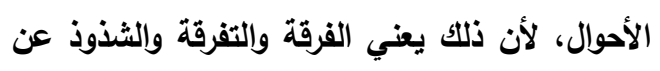
القاعدة الوطنية التي تجسد حب الوطن، (الصرابي، 2013، ص 226). يُعرف بأنه الانتساب إلي كيان ما يكون الفرد متوحداً

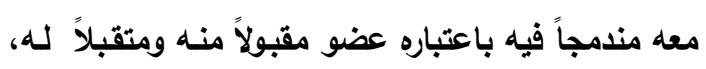
وله شرف الانتساب إليه، ويثعر بالأمان فيه، وقد يكون هذا الكيان جماعة أو طبقة أو وطن، وينطوي على الولاء

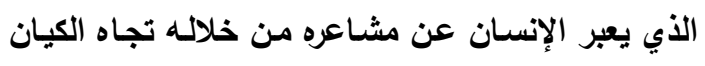
الأي ينتمي إليه،(درويش، 2009، ص 267 201ن. ويُعرف بأنه ارتباط بين الفرد والمجتمع، ويظهر على

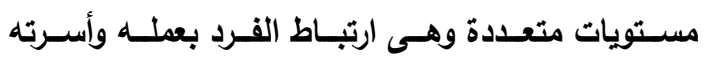

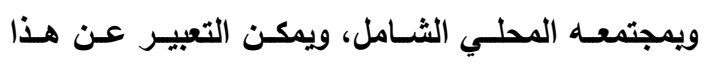

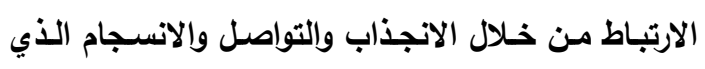

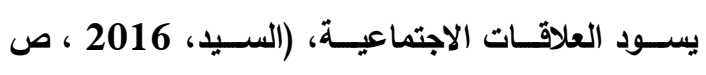

ويؤكد درويش ( 2009 ، ص 267) علي الانتماء

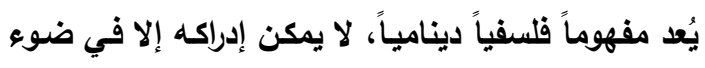

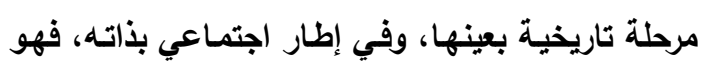
نتــاج للعديـــ مسن المعطيـات والمتغيـرات الاجتماعيـة

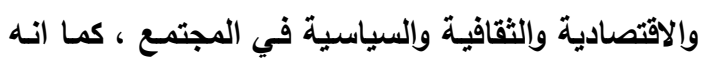

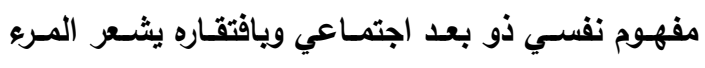
بالعزلة ويعريـه الضيق وتنتابـه المشكلات النفسية التي فئي لها تأثيرها على وحدة المجتمع وتماسكه. وتري عرب ( 2018، ص94) أن الانتماء يظهر في

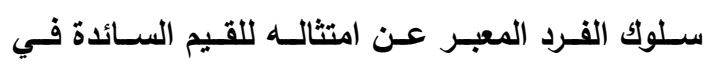
مجتمعهوالالتزام بـالقوانين والأنظمة السـائدة، والمحافظة المئهة

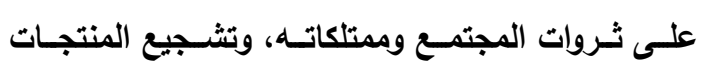

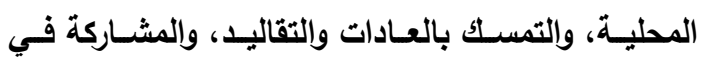


الفرد الثعور بالقوة، وعليه أن يسعى جاهداً إلى تجربـة

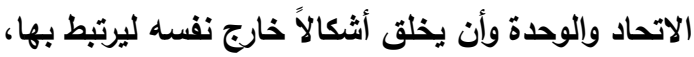
تحل محل الاتحساد بالأسـرة مثل (المدرسـة - النـادي -

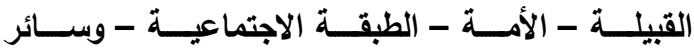

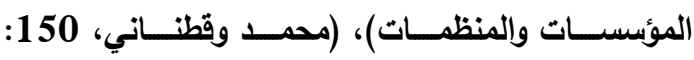

2- نظريـة تثـارلز رايت ميلز Charles R. Mills: حيث يرى أن الانتماء الحقيقي يتم عندما يتحقق للى لدئ

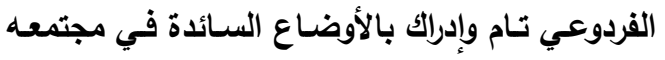

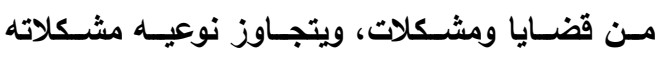

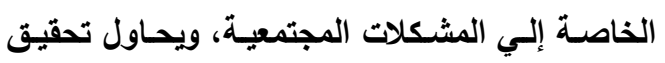

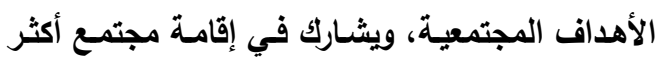

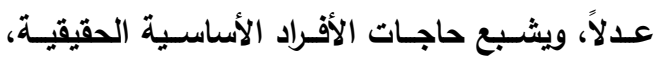
ويتحقيقها يحقق الفرد ذاته، ويشـعر بالرضـا والفخر

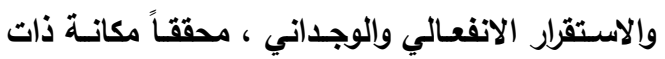
تقدير اجتمـاعي، فالانتمـاء هو الطريق إلـي الأمسان وتقدير الذات وتحقيق النمو والتقدم، (خضر، فئماءل 2000،

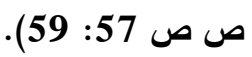

\section{ثانياً: الاستعراض المرجعي}

في ضوء الدراسات ذات الصلة بموضوع البحث والتي

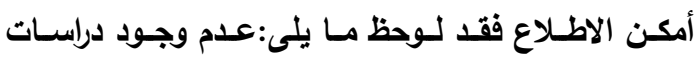

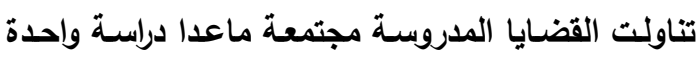

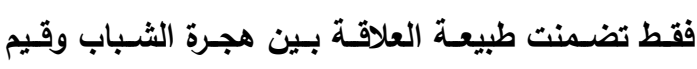

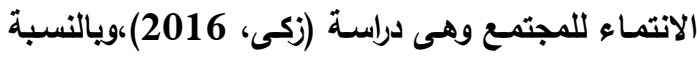

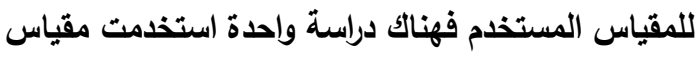
الانتمـاء الأسـرى والمجتمعسي مسن خـلال ثلاثـة أبعـاد

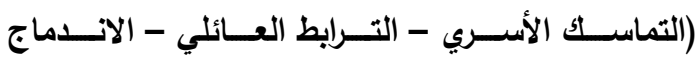
المجتمعسي) وهـى دراســة (الريــدي ، 2008)، وأخـري

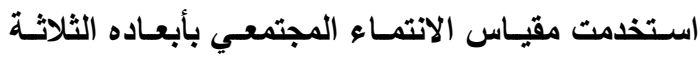

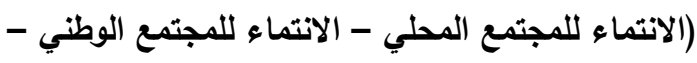

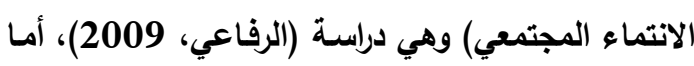

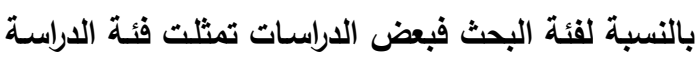
بها في الثباب الريفي ومن هذه الاراسات دراسة(الريدي، 2008)، و(الرفاعي، 2009)، و (زكى، 2016).
حتى تكاليف يوم الزفاف كالحفلات ويطاقات الدعوة والملابس والهـدايا والأثاث الفـاخر والأجهزة الحديثة ومتطلبات إجراء ليلة الزفاف، الأمر الذي خلط التقاليد

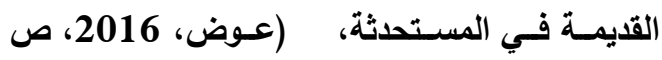

6- وسائل التواصل الاجتماعي:تعني الوسائل الاكترونية

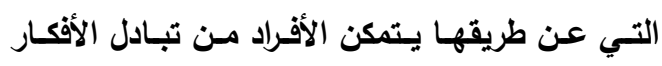

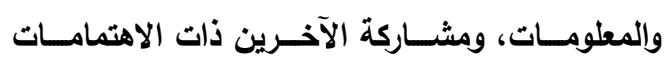

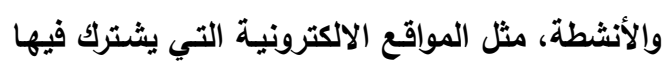
العليد من الأفراد والتي يستطيع المشترك عن طريقها

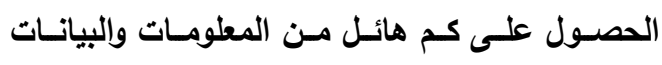

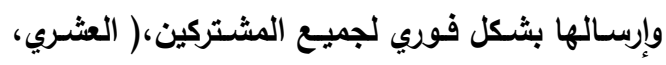
2014، ص 34).

7 - الهجرة الخارجيـة: يقصـ بهـا الأفراد الـين عبروا

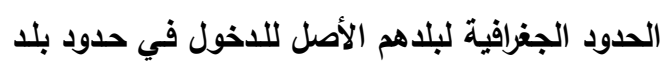

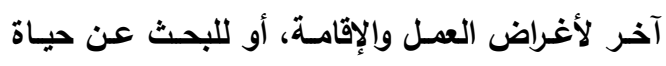

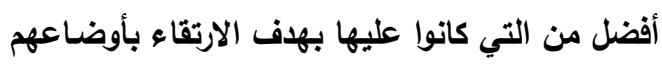

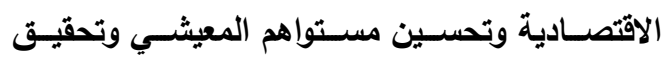
توقعاتهم من وراء الهجرة، أو بسبب ظروف اجتماعية أو سياسية أو طبيعية تضطرهم إلى ترك بلدهم الأم، ألماء

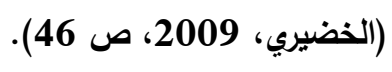
ب- التوجهات النظرية المفسرة للانتماء يستند البحث الحالي إلي نظريتين هما:

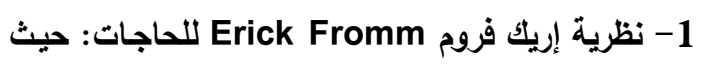
أشـار إلـي أن فهم النفس البشرية يقوم على تحليل

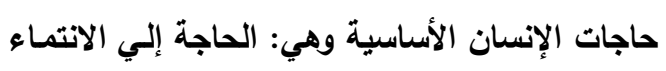

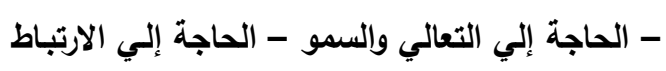

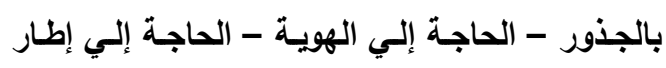

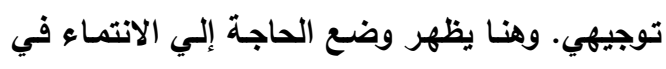
مقدمة الحاجات الضرورية، (العرجا وتيسير عبد الله،

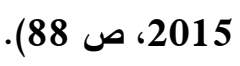
واعتبر فروم الانتماء إحساساً وشعوراً، وأن الحاجة إليه هى الحاجة إلى كيان أثثمل وأكثر قدرة يستمد منـه 
ثانياً: شاملة الدراسة وطريقة اختيار العينة البحثية

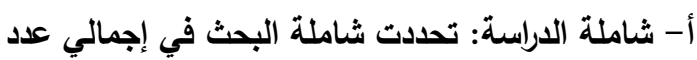
الثباب (ذكور - إناث) في الفئة العمرية من (2035) سنة، والمقيمين في القري الثلاثة التي وقع التعابة عليها الاختيارويلغ عددهم (14293) شناباً. ب- عينة الاراسة: استخدمت معادلة (كريس ومورجان، 1970) في تحديد حجم العينـة فبلغت 375 شـاباً موزعة كالتـالي (205 من قريـة فيثـا سليم، و 11670 من قرية خرسيت، و54 من قرية كفر سبطاس)، وتم

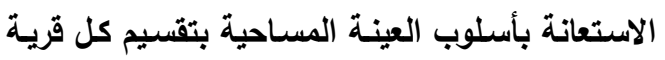

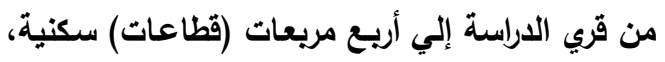
ومن كل مريع تم اختيار المبحوثين الشبابالذين ينطبق الثبق عليهم الشروط بطريقة عشوائية. ثالثاً: أسلوب جمع البيانات:

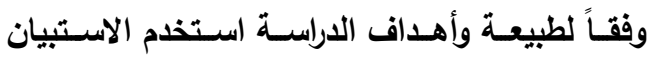

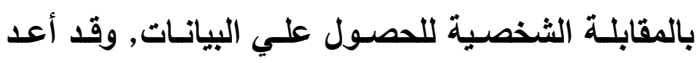
متسقاً مـع أهداف الدراسـة, وقدابل مرت استمارة الاستبيان بعدة مراحل بـداء بـإجراء الصـحة الظاهريـة للاستمارة بعرضـها علـي الأسـاتذة المتخصصين للتحكيم، وإجـراء التعديلات المطلويـة، ثم إجراء اختبار مبلئي للاستمارة علي عينـة قوامها (30) مبحوثاً من الثباب في الفئة الفئة العمريـة مـن (20-35) سـنـمن خـارج قـري الاراسـة. وأخيراً تم تدقيق الاستمارة وإعدادها في صورتها لنئ النهائية.

رابعاً: المتغيرات البحثية وكيفية قياسها

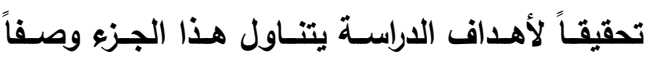
للمتغيرات البحثية المستخدمة في الدراسة وكيفية قياسها: أولاًا- المتغيرات المستقلة وتتقسم إلي جزئيين هما: أ- الخصائص الشخصية لأفراد العينة البحثية

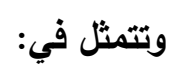

1- العمر : ويقصد به عدئ سند سنوات عمر المبحوث من وقت الميلاد حتى وقت جمع البيانات كرقم خام.
وانطلاقاً منذلك فالبحث الحالي تتضمن دراسة لبعض القضايا المعاصرة سواء الاقتصادية مثل (الخصخصة -

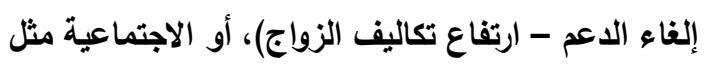
(استخدام وسائل التواصل الاجتماعي - الهجرة الخارجية)

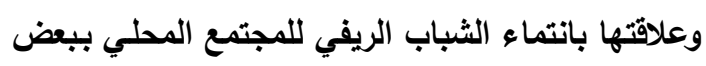
قري بمحافظة الغربية.

$$
\text { الفروض البحثية }
$$

1- توجـــ علاقــة ارتباطيـة بـين المتغيـرات المسـتقلة المدروسـة ويبين درجـة كل مؤثـر من المؤشراتالستة

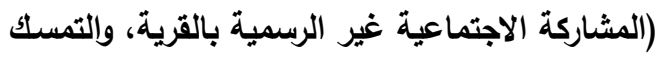

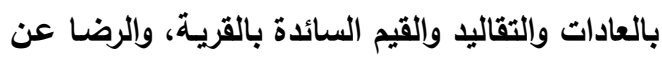

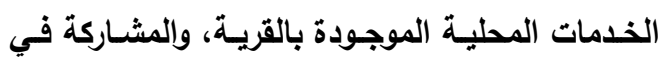
الأعمال التطوعية والخيرية بالقرية، والارتباط بمجتمع بالهي

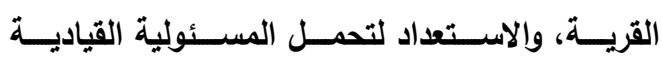

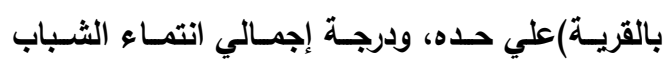
الريفي للمجتمع المحلي.

2- يسـهم كلمتغير مسن المتغيرات المستقلة المدروســة

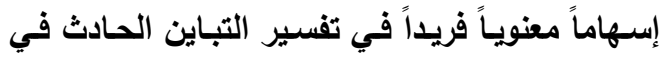
درجة كل مؤثر من المؤشرات الستة علي حده ودرجة إجمالي انتماء الثباب الريفي للمجتمع المحلي.

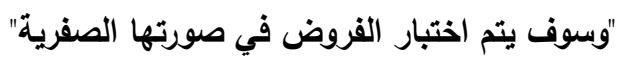
الطريقة البحثية أولاً: منطقة البحث تم اختيار ريف مركز طنطا محافظة الغربية مجالاً جغرافيـاً لإجراء الدراسـة الميدانيـة، وجـاء الاختيـار لأنسه الموطن الأصلي للباحثة ومحل عملها مما يسهل عملية جمع البيانـات، بالإضـافة إلي تأصيل مبدأ خدمة البحث

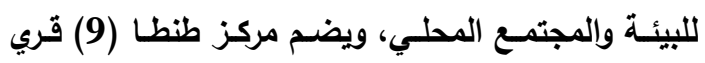

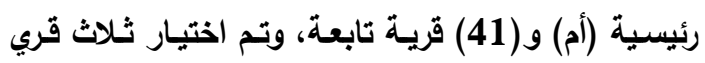

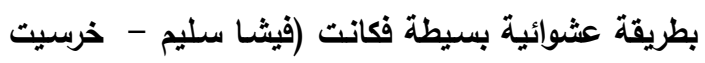
- كفر سبطاس ). 
6- حيازة الأسرة للأجهزة المنزلية: ويقصد بها ما تحوزه أسرة المبحوث مـن أجهزة منزليـة، وقد تـم إعطائهـا

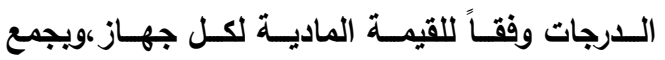
اللدرجات التـي حصل عليها المبحوث يكون النـاتج معبراً عن الارجة الكلية لحيازة أسرة المبحوث للأجهزة

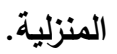

7- الطموح: ويقصد بـه المستوي الذي يتطلع المبحوث لبلوغه حتي يحقق مستوي اقتصادي واجتماعي أفضل

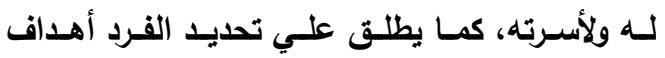

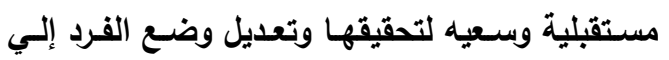
الأفضل. وتم قياسه بمقياس مكون من (9) عبارات.

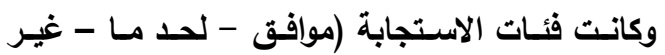

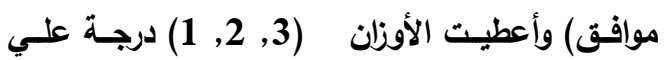

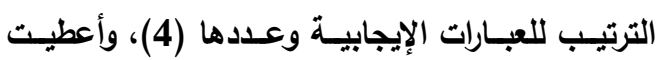

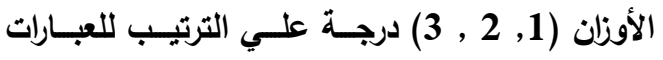

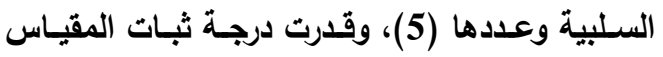

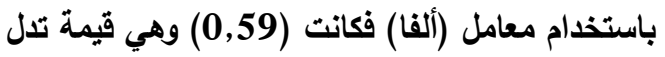
علـي ثبـات المقيـاس. ثـم جمعـت درجـات العبـارات للحصول علي الارجة الكليةتلطموح, وتراوحت القيمة فئة النظرية ما بين (9 - 27) درجة.

8- التجديدية: ويقصد بها مدي تقبل المبحوث لكل مـا هو جديد من أفكار وعناصر تكنولوجية، والنظر إليها بعين التقدير والاحترام، وعدم التمسكبما هو موروث من الأجيال السابقة، وتم قياسـها بمقياس مكون من وعلامن

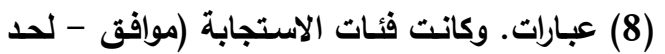
ما - غير موافق) وأعطيت الأوزان (3, 2, 1 1) درجة الانجة علي الترتيب للعبارات الإيجابية وعددها (4)، وأعطيت الأوزان (1, 2 , 3) درجـة علــي الترتيـب للعبـارات

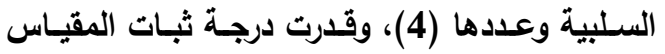

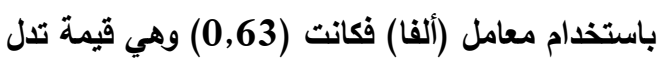
عـي ثبـات المقيـاس. ثـم جمعـت درجـات العبـارات

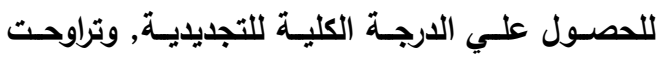

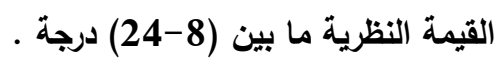

2- عدد سنوات التعليم: ويقصد بها عدد السـنوات الاراسية التي أتمها المبحسوث بنجـاح خـلال مراحل التعليم الرسمي كمؤشر رقمي، وأعطيت درجة واحدة لكل سنة أتمها المبحوث بنجاح. 3- حجم الأسرة: ويقصد بـه إجمـالي عدد أفراد أسرة

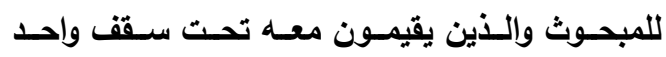

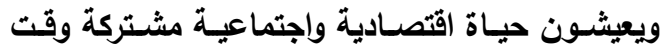
جمع البيانات، وتم قياسه برقم خام. 4- الاخل الثهري للأسرة: ويقصد بـه إجمالي الإيرادات

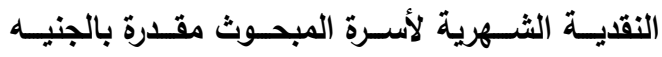
المصري وقت جمع البيانات.

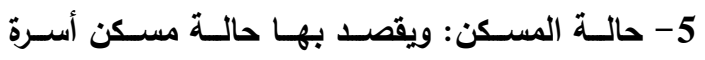

$$
\text { المبحوث من حيث: }
$$

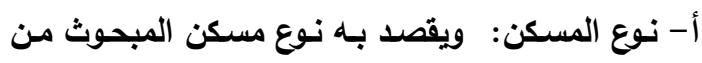

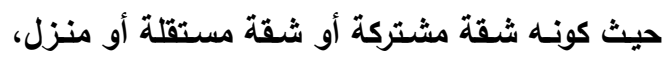

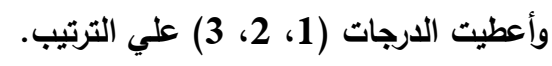

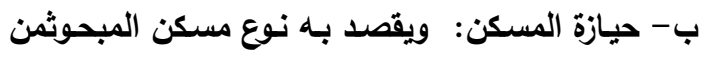
حيث كونـه إيجار أو ملك، وأعطيث الدرجات (1، علي الترتيب. ج- عدد الطوابق: يقصد بـه عدد طوابق المنزل، وتم قياسه برقم خام يعبر عن عدد طوابق المنزل.

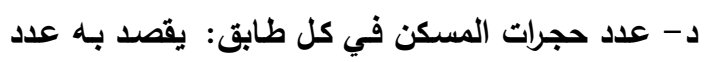

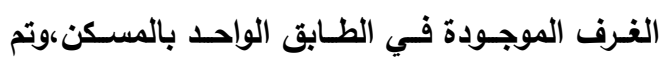
قياسه برقم خام يعبر عن عدد الغرف.

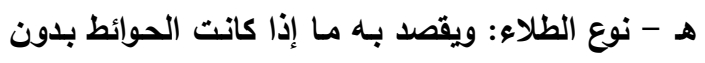

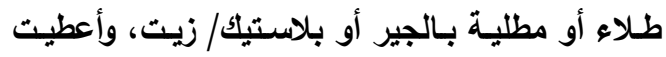
الارجات (1، 2، 3) علي الترتيب.

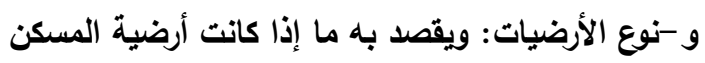

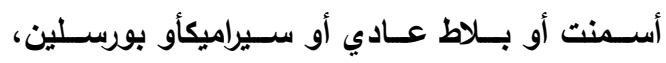

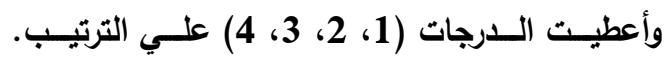
ويجمع الدرجات التي حصل عليها المبحوث في كافة بنود القياس السـابقة يكون الناتج معبراً عن الدرجة الدئ الكلية لحالة مسكن. 
وقدرت درجة ثبات المقيـاس باستخدام معامـل (ألفا)

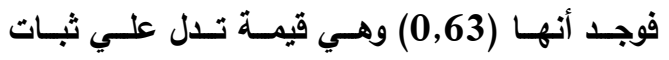

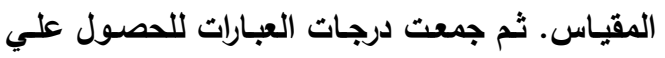
الدرجـة الإجمالية للمقياس، وتراوحت القيمـة النظريـة ما بين (16- (48) درجة. ب- قضية إلغاء الدع: ويقصد بها رأي المبحوث في أن

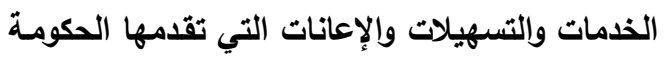

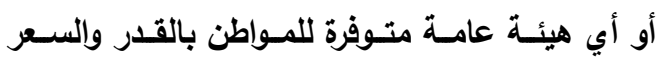

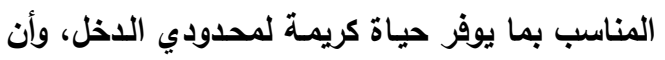

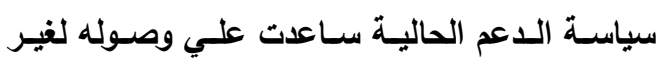
المستحقين كما شجعت علي سوء الاستهلاك وتثشوه

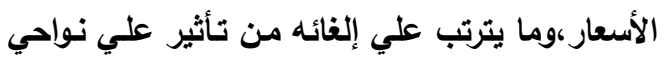

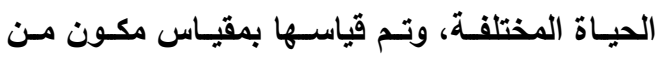
(15) عبارة. وكانت فئات الاستجابة (موافق - موافق

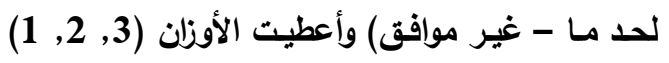

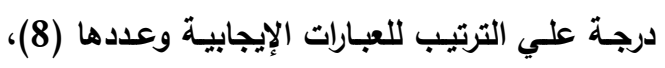

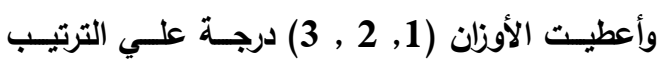
للعبـارات السـلبية وعددها (7)، وقدات المات درجـة ثبـات

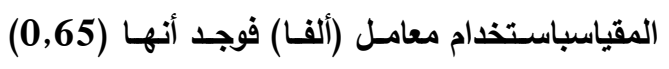
وهي قيمة تدل علي ثبات المقياس. ثم جمعت درجات

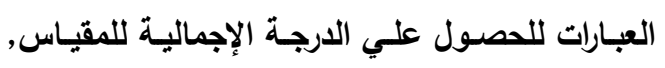
وتراوحت القيمة النظرية ما بين (15- 45) درجة. ج- قضية ارتفـاع تكـاليف التزواج: ويقصد بها رأي

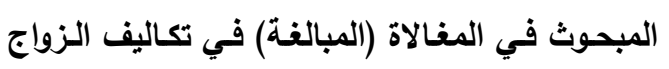

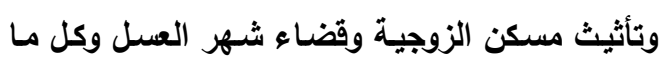
يحيط بـذلك مـن مظاهر البذخ الاجتمـاعي والتفـاخر

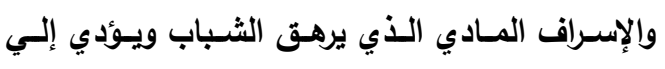
التأخير في الزواج والسلف واللديون ويبع المنتكات ممـا يؤثر علي نواحي الحياة المختلفة، وتم قياسـها من خلال (13) عبارة. وكانت فئات الاستجابة (موافق

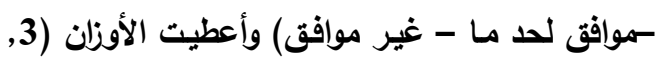

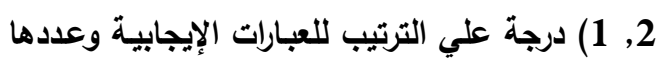

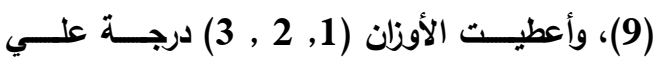

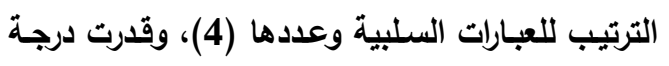

9- الادفعية للإنجاز : ويقصد بها درجة استعداد المبحوث لإنجاز أعماله بسرعة وإتقان في المدة المحددة مهما كلفه من مجهود، وشعوره بالرضا عند إنجاز الأعمال

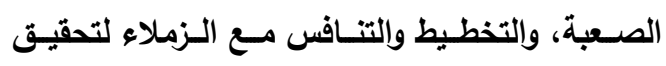
الأهـاف، وتـم قياسـهـا بمقيـاس مكــون مسن (10) عبارات.وكانت فئات الاستجابة (دائما - أحيانا - نادرا

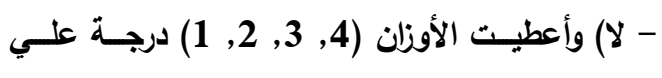

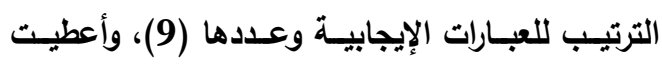
الأوزان (1, 2 , 3, 4) درجـة علـي الترتيب للعبـاراة السـلبية، و قدرت درجـة ثبـات المقيـاس باسـتخدام

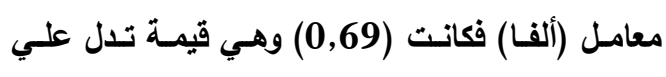
ثبات المقياس. ثم جمعت درجات العبارات للحصول

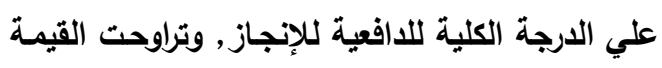
النظرية ما بين (10-40) درجة.

ب- القضـايا المعاصرة المدروسـة: اشتملت الدراسـة علي نوعين من القضايا هما:

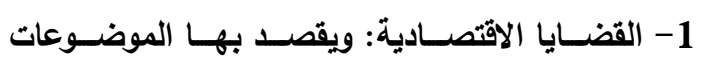
الموجودة في المجتمع والمتعلقة بالجاتب الاقتصادي

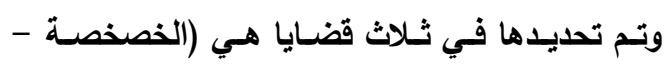
إلغاء الدعم - ارتفاع تكاليف الزواج). أ- قضية الخصخصة: ويقصد بها رأي المبحوثفي إحلال

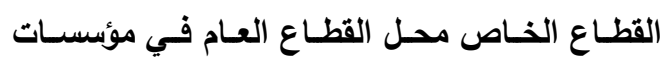
الدولة، وما يترتب علي ذلكمن زيادة المرونـة والحريـة

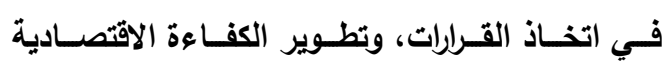

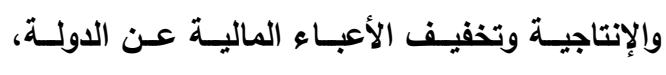
وموافقته علي أن العاملين في القطاع الخاص أكثر الأثر

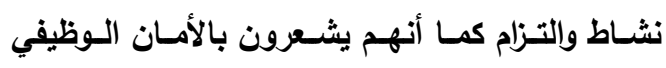

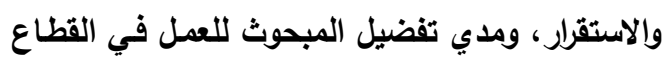

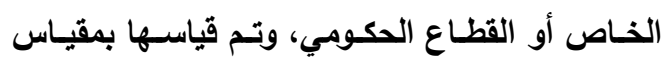

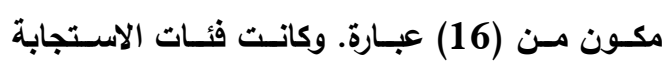

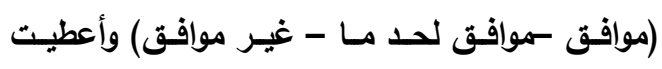

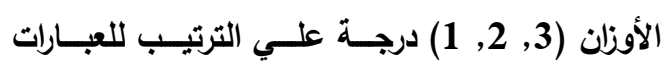

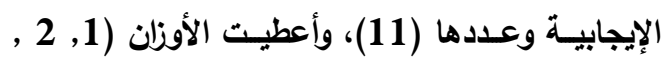
3) درجة علي الترتيب للعبارات السلبية وعددها (5)، والإولان (11) 
الترتيب للعبارات السلبية وعددها (5)، وقدرت درجة

ثبـات المقيـاس باسـتخدام معامـل (ألفـا) فوجــ أنهـا

(0,69) وهي قيمة تلال علي ثبات المقياس.ثم جمعت بالثة

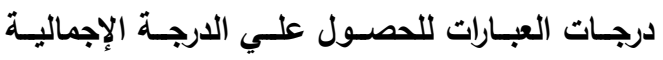

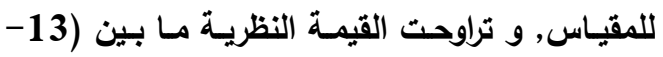

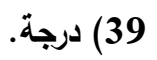

ثانيا: المتغير التابع (الانتماء للمجتمع المحلي):

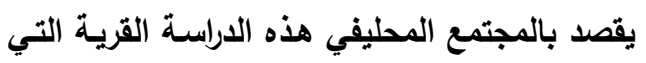
يعيش بها المبحوث، وتم قياس انتمـاء الثباب الريفي لمئي

للمجتمع المحلي من خلال (6) مؤثرات هي: 1- المشاركة الاجتماعية غير الرسمية بالقرية: ويقصد بها رأي المبحوث عن مدي مشـاركته للجيران وأهل

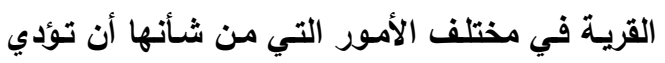

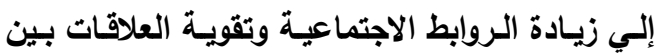

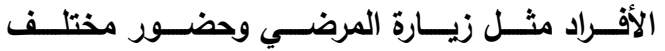

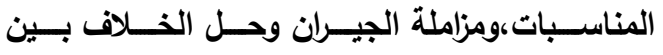
المتنازعين وما إلي ذلك، وتم قياسـها بمقياس مكون

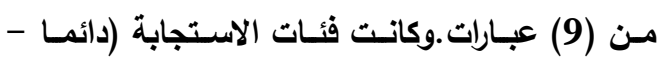

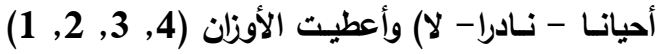

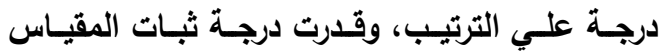
باستخدام معامل (ألفا) فوجد أنها (0,79) وهي قيمـة درجة تـدل علـي ثبـات المقيساس.ثم جمعتدرجات العبـارات للحصول علي الدرجـة الإجماليـة للمقيـاس, وتراوحت القيمة النظرية ما بين (9- 36) درجة.

2- التمســك بالعـــادات والتقاليــــ والقــيم الســـائدة بالقرية:ويقصـد بهـارأي المبحـوث عن مـدي الالتزام

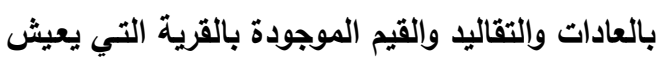
فيها مثل التسـامح والنصـح ومراعاة شعور الآخرين في حالات الحزن والوفاة والفرح واحترام الأكبر سناؤما إلـي ذلــك،وتم قياسـهـا بمقيساس مكسون مسن (11) عبارة.وكانت فئات الاستجابة (بدرجة كبيرة - بلرجة

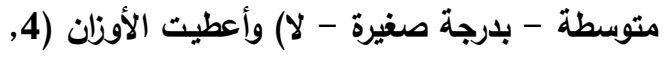
3, 2, 1) درجـة علـي الترتيـب للعبـارات الإيجابيـة
ثبـات المقيـاس باسـتخدام معامـل (ألفـا) فوجــ أنهـا

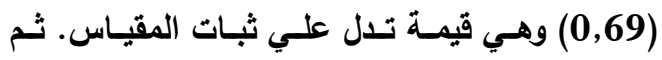

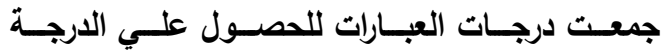
الإجمالية للمقياس, وقد تراوحت القيمـة النظريـة مـا بين (13- 39) - 3وجة.

2- القضــايا الاجتماعيـة: ويقصـــــــــا الموضــوعات الموجودة في المجتمع والمتعلقة بالجانب الاجتمـاعي وتـم تحديـدها فـي قضـيتين همـا (اسـتخدام وسـائل التواصل الاجتماعي، والهجرة الخارجية). أ- قضية استخدام وسـائل التواصل الاجتمـاعي: ويقصد

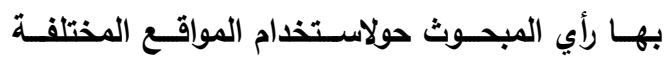

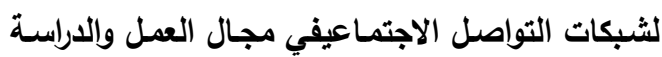
والتواصل بين الأهل والأصدقاء المهاجرين، مما يؤثر الأثرال

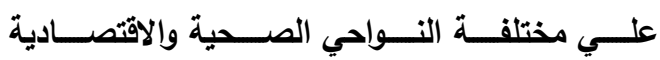
والاجتماعية والداينية والسياسية والنفسية، وتم قياسها

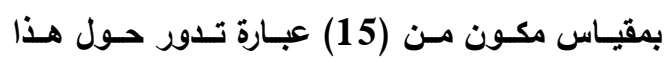
المعني.وكانت فئات الاستجابة (موافق -موافق لحد ما

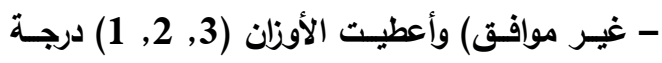

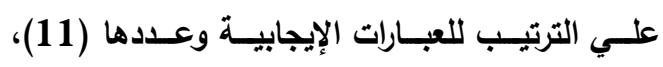

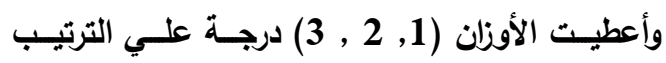

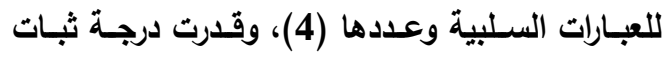
المقياس باستخدام معامل (ألفا) فوجد أنها (0,73) وهي قيمة تلال علي ثبات المقياس.ثم جمعت درجات

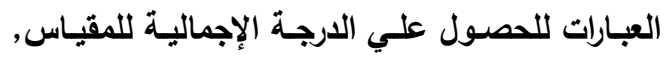
وتراوحت القيمة النظرية ما بين (15- 45) درجة. ب- قضية الهجرة الخارجيـة: ويقصد بها رأي المبحوث

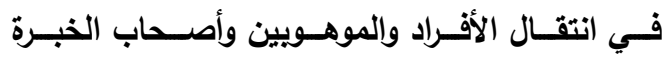
والحـرفيين مـن المجتمـع الأصـلـي إلــي دولــة أخـري لأسباب اقتصادية أو اجتماعية وما إلي ذلك مما يؤيثر التئي

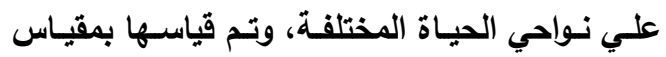

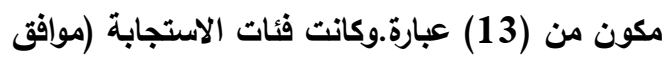

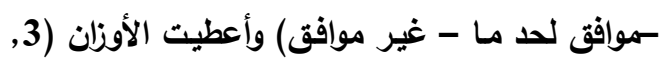
2, 1) درجة علي الترتيب للعبارات الإيجابية وعددها

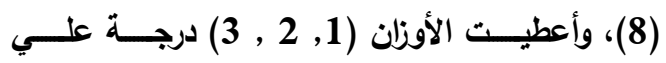


ورغبتهـه في البقـاء والعيش بهـا، والتعلق والارتبـاط العاطقي بأهل القرية، وتم قياسـه بمقياس مكون من (10) عبارات.وكانت فئات الاستجابة (بدرجة كبيرة -

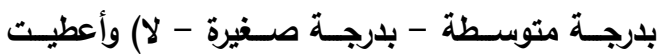
الأونان (4, 3, 2, 1) درجـة علـي الترتيب للعبـارات الإيجابية أرقام وعددها (7)، وأعطيت الأوزان (1, 1 (1) 2 (1) 3, 4) درجة علي الترتيب للعبارات السلبية وعددها (3)، وقدرت درجة ثبات المقيـاس باستخدام معامـل

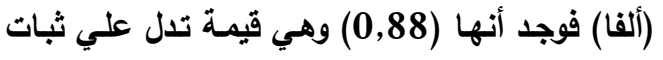

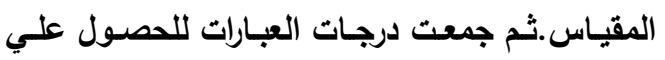
الدرجـة الإجمالية للمقياس, وتراوحت القيمـة النظريـة ما بين (10 - 10 (40) درجة. 6- الاستعداد لتحمل المسئولية القيادية بالقرية:ويقصد

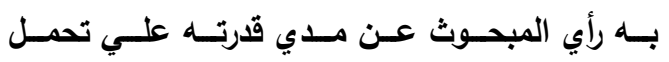

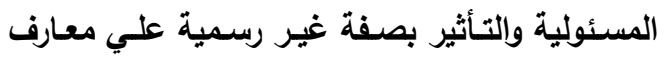
واتجاهـات وسـلوك أهل القريسة،ولجوء الآخرين إليسه

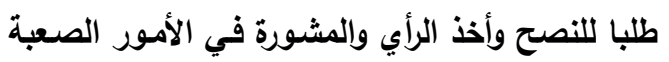

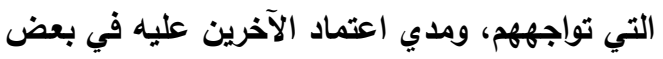
المواقف، وتم قياسه بمقياس مكون من (9) عبارات.

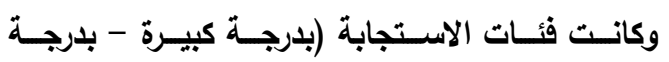
متوسطة - بدرجة صغيرة - لا) وأعطيت الأوزان (4) 3, 2, 1, 1) درجـة عـــي الترتيـب للعبـارات الإيجابيـة

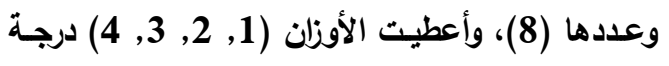

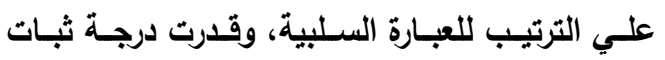
المقياس باستخدام معامل (ألفا) فوجد أنها (0,76) وهي قيمة تدل علي ثبات المقياس.ثم جمعت درجات بات

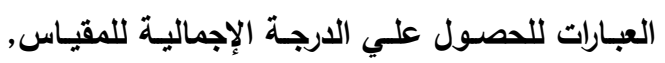
وتراوحت القيمة النظرية ما بين (9- 36) درجة. إجمـالي الانتمـاء للمجتمـع المحلي: وتـم قياسـه مـن

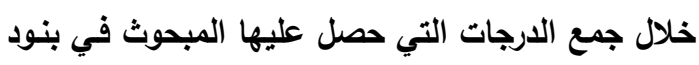

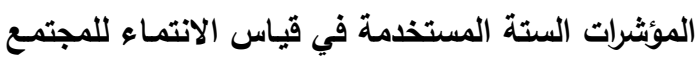

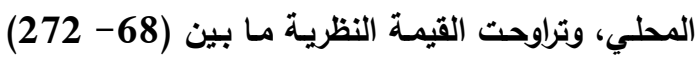
درجة.
وعددها (8)، وأعطيت الأوزان (1, 2, 3, 4) درجـة علي الترتيب للعبارات السلبية وعددها (3)، وقدرت درجة ثبات المقياس باستخدام معامل (ألفا) فوجد أنها

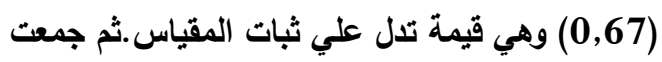
درجـات العبـارات للحصـول علــي الارجــة الإجماليـة

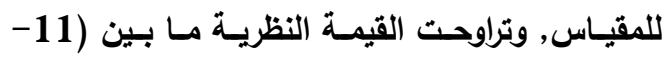
44 3- الرضــا عـن الخـامات المحليـة الموجـودة بالقريـة: ويقصد بـه رأي المبحوث عن وجـود الخدمات التـي تقدمها المنظمـات الموجـودة في محيط القريـة التي لـي يعيش بها من عدمسه، وإذا وجدت الخدمة تم سؤاله عن درجة رضاه عنها، وتم قياسهيمقياس مكون من عن واندات

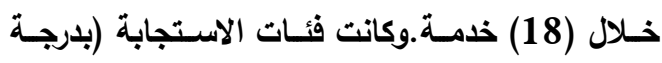

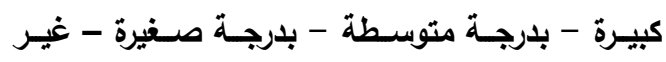

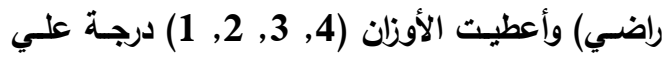

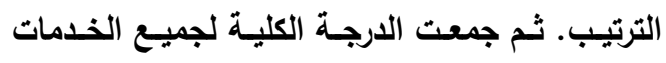

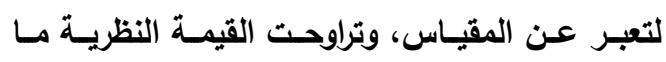
بين(18- 18 (12) درجة.

4- المثـــاركة فــــي الأعمــال التطوعيــة والخيريســة بالقرية:ويقصد بها رأي المبحوث عن مدي الاندماج مع الجماعة والعمل بروح الفريق والمشاركة والتكامل بلديل والتفاعل الايجابي، بالإضافة إلي التعاون مع الآخرين

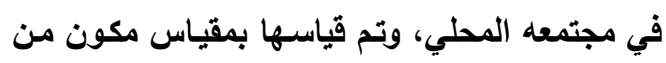

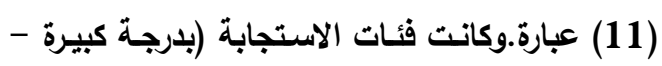

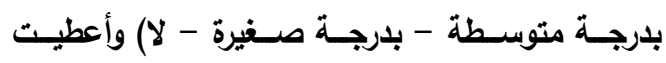

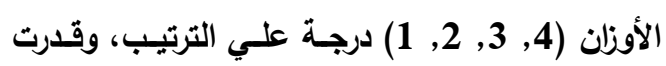
درجة ثبات المقياس باستخدام معامل (ألفا) فوجد أنها (0,84) وهي قيمة تدل علي ثبات المقياس.ثم جمعت باتثات

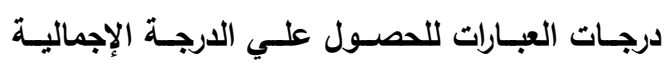

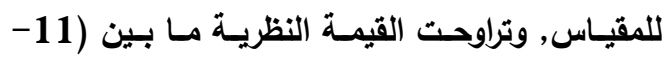
44) درجة. 5- الارتبـاط بمجتمـع القريـة: ويقصد بـه رأي المبحـوث

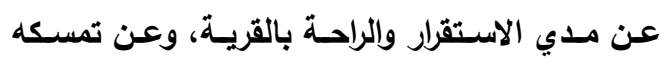


العينة البحثية (63,5\%) مستوي اتجاههم نحو قضية ارتفاع تكاليف الزواج متوسط، وما يزيد عن ثلاثة أرباع أفراد العينـة البحثيـة (76,5\%) مستوي اتجـاههم نحو قضية استخدام وسائل التواصل الاجتماعي متوسط, ومـا يقرب من ثلاثـة أريـاع أفراد العينـة البحثيـة (71,7\% مستوي اتجاههم نحو قضية الهجرة الخارجية متوسط. ثنانياً: مستوي الانتمـاء للمجتــع المحلـي بمؤشـراته الستة المدروسة الائة

يعرض جدول (2) توزيع أفراد العينـة البحثية وفقاً

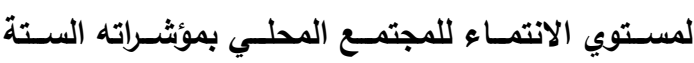
المدروسة، ويتضح من بيانات الجدول ما يلي: الغالبية العظمي من أفراد العينة البحثية (98,7\%) مستوي المشاركة الاجتماعية غير الرسمية بالقرية لايهر ما بين المتوسط والمرتفع، وما يقرب من ثلاثة أرباع أفراد

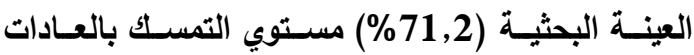

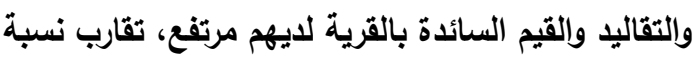
مستوي الرضـا عن الخدمات المحلية الموجودة بالقريـة لاي أفراد العينة البحثية في الفئات الثلاثة (المنخفض، والمتوسط، والمرتفع)، مـا يقرب من ثلثي أفراد العينـة البحثيــة (63,7\%) مســتوي المشــاركة فــي الأعمــال التطوعيـة والخيريـة بالقريـة لليهم مرتفع، وغالبيـة أفراد

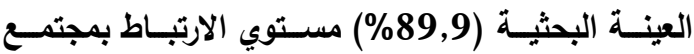
القريـة للايهم مـا بين المتوسط والمرتفع، مـا يقرب من الن

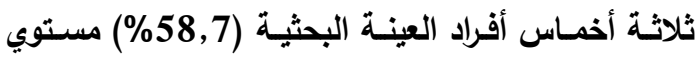

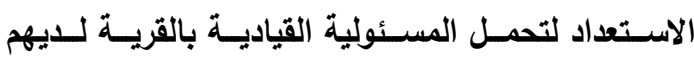

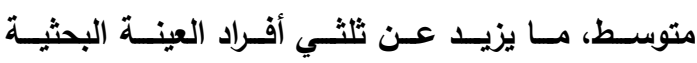
(\%66,6 مسـتوي إجمـالي الانتمــاء للمجتمـع المحلـي لايهجم متوسط.
الأساليب الإحصائية

تـم استخدام التكرارات, والنسب المئويـة, والمتوسط المسط الحسابي, والانحراف المعياري, ومعامل الارتباط البسيط (بيرسون)، ومعامل الارتباط المتعدد, والانحدار الجزئسي المعيـاري، كمـا استخدم معامـل " ألفـا كرونبـاخ " لتقدير درجة ثبات المقاييس المتعددة البنود.

$$
\text { نتائج البحث }
$$

أولاً: وصف المتغيرات المستقلة لأفراد العينة البحثية يعرض جدول (1) توزيـع أفراد العينـة البحثية وفقاً للمتغيرات المستقلة المدروسة ويتضح من بيانات الجدول

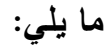

أن مــــــــب مسن نصــف أفــراد العيـــة البحثيـة (49,6) في الفئة العمرية(31 - 35 سنة)، وما يزيد

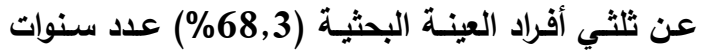

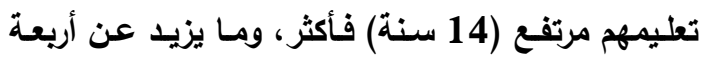

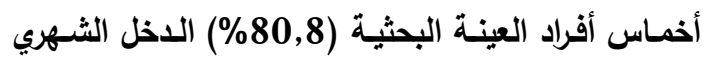
لأسرهم ما بين المنذفض والمتوسط، وما يزيد عن أريعة أخمـاس أفراد العينـة البحثيـة (84,3\%) حالـة المسكن للديهم متوسطة، وثلاثـة أخمـاس أفراد العينـة البحثيـة (\%60,5) حيـازة أسـرهم للأجهـزة المنزليـة متوسـطة،

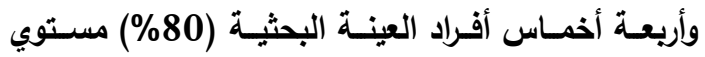
الطموح لايهم مرتفع، ومـا يقرب من ثلاثة أخماس أفراد

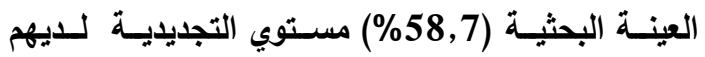
متوسط، وغالبية أفراد العينة البحثية (89,8\%) مستوي

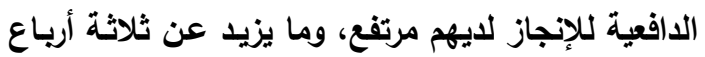

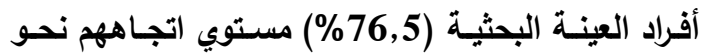
قضية الخصخصة متوسط, وحوالي ثلاثة أخماس أفراد العينة البحثية (59,2\%) مستوي اتجـاههم نحو قضية إلغاء الدعم متوسط، ومـا يزيد عن ثلاثة أخماس أفراد 
جدول (1): توزيع أفراد العينة البحثية وفقا مللمتغيرات المستقلة المدروسة.

\begin{tabular}{|c|c|c|c|c|c|c|c|}
\hline$\%$ & 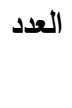 & 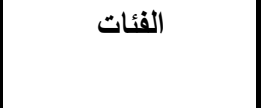 & المستقلة الميرات & $\%$ & 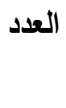 & الفئـات & المتتغيرات \\
\hline 0,5 & 2 & منخفض (8 - 12 درجة) & \multirow[t]{4}{*}{ التجديدية } & 22,4 & 84 & الفئة العمرية الأولي (20 - أقل من 25 سنة) & \\
\hline 58,7 & 220 & متوسط (13 -19 درجة) & & 28 & 105 & الفئة العرية الثانية (25 - أقل من 31 سنة) & \\
\hline 40,8 & 135 & مرتفع (20 - 24 درجة) & & 49,6 & 186 & الفئة العمرية الثالثة (31 - 35 سنة) & \\
\hline 100 & 375 & المجموع & & 100 & 375 & المجموع & \\
\hline 0,3 & 1 & منخفض (10-19 درجة) & \multirow[t]{4}{*}{ الدافعية للإنجاز } & 1,9 & 7 & صغير (6 - 9 سنة دراسية) & \multirow[t]{4}{*}{ عدد سنوات التعليم } \\
\hline 9,9 & 37 & متوسط (20 -30 درجة) & & 29,8 & 112 & متوسط (10 - 13 سنة دراسية) & \\
\hline 89,8 & 337 & مرتفع (31 - 40 درجة) & & 68,3 & 256 & كبير (14 سنة دراسية فأكثر) & \\
\hline 100 & 375 & | المجموع & & 100 & 375 & المجموع & \\
\hline 7,2 & 27 & منخفض (16 -26 درجة) & \multirow[t]{4}{*}{ قضية الخصخصة } & 19,7 & 74 & أسرة صغيرة (1 - 3 أفراد) & \multirow[t]{4}{*}{ 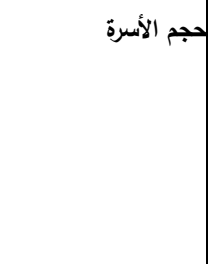 } \\
\hline 76,5 & 287 & متوسط (27 - 37 درجة) & & 71,8 & 269 & أسرة متوسطة (4 - 6 أفراد) & \\
\hline 16,3 & 61 & مرتفع (38 - 48 درجة) & & 8,5 & 32 & أسرة كبيرة (7 أفراد فأكثر) & \\
\hline 100 & 375 & المجموع & & 100 & 375 & المجموع & \\
\hline 40 & 150 & منخفض (15- 24 درجة) & \multirow[t]{4}{*}{ قضية إلغاء الدعم } & 41,3 & 155 & منخفض (1000 - أقل من 3000 جنيه) & \multirow[t]{4}{*}{ | الدخل الثهري للأسرة } \\
\hline 59,2 & 222 & متوسط (25 - 35 درجة) & & 39,5 & 148 & متوسط (3000 - أقل من 5000 جنيه) & \\
\hline 0,8 & 3 & مرتفع (36 - 45 درجة) & & 19,2 & 72 & مرتفع (5000 جنيه فأكثر) & \\
\hline 100 & 375 & المجموع & & 100 & 375 & المجموع & \\
\hline 34,1 & 128 & منخفض (13- 21 درجة) & \multirow{4}{*}{ |الزواجية ارتفـاع تكـاليف } & 6,9 & 26 & منذفضة (7 - 11 درجة) & \multirow{4}{*}{ حالة المسكن } \\
\hline 63,5 & 238 & متوسط (22 - 30 درجة) & & 84,3 & 316 & متوسطة (12 - 17 درجة) & \\
\hline 2,4 & 9 & مرتفع (31 - 39 درجة) & & 8,8 & 33 & مرتفعة (18 - 22 درجة) & \\
\hline 100 & 375 & | المجموع & & 100 & 375 & المجموع & \\
\hline 3,7 & 14 & منخفض (15- 24 درجة) & \multirow{4}{*}{ 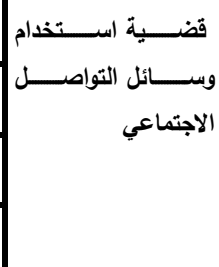 } & 14,4 & 54 & صغيرة (أقل من 24 درجة) & \multirow[t]{4}{*}{ حيـازة الأسـرة للأجهـزة } \\
\hline 76,8 & 288 & متوسط (25 - 35 درجة) & & 60,5 & 227 & متوسطة (24- 38 درجة) & \\
\hline 19,5 & 73 & مرتفع (36 - 45 درجة) & & 25,1 & 94 & مرتفع (39 درجة فاكثر) & \\
\hline 100 & 375 & المجموع & & 100 & 375 & المجموع & \\
\hline 4 & 15 & منخفض (13- 21 درجة) & \multirow[t]{4}{*}{ قضية الهجرة الخارجية } & صفر & صفر & منذفض (9 - 14 درجة) & \multirow{4}{*}{ الطموح } \\
\hline 71,7 & 269 & متوسط (22 - 30 درجة) & & 20 & 75 & متوسط (15 - 21 درجة) & \\
\hline 24,3 & 91 & مرتفع (31 - 39 درجة) & & 80 & 300 & مرتفع (22 - 27 درجة) & \\
\hline 100 & 375 & | المجموع & & 100 & 375 & المجموع & \\
\hline
\end{tabular}


جدول (2): توزيع أفراد العينة البحثية وفقاً لمستوي الانتماء للمجتمع المحلي بمؤثراته الستة المدروسة.

\begin{tabular}{|c|c|c|c|}
\hline$\%$ & 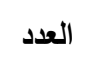 & الفئات & الانتماء للمجتمع المحلي \\
\hline 1,3 & 5 & ضعيف (9 - 17 درجة) & \multirow{4}{*}{ المشاركة الاجتماعية غير الرسمية بالقرية } \\
\hline 44 & 165 & متوسط (18 - 27 درجة) & \\
\hline 54,7 & 205 & مرتفع (28 - 36 درجة) & \\
\hline 100 & 375 & المجموع & \\
\hline 0,3 & 1 & ضعيف (11 - 21 درجة) & \multirow{4}{*}{ التمسك بالعادات والثقاليد والقيم السائدة بالقرية } \\
\hline 28,5 & 107 & متوسط (22 - 33 درجة) & \\
\hline 71,2 & 267 & مرتفع (34 - 44 درجة) & \\
\hline 100 & 375 & 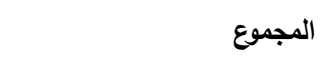 & \\
\hline 38,9 & 146 & ضعيف (18 - 35 درجة) & \multirow{4}{*}{ الرضا عن الخدمات المحلية الموجودة بالقرية } \\
\hline 28,8 & 108 & متوسط (36 - 54 درجة) & \\
\hline 32,3 & 121 & مرتفع (55 - 72 درجة) & \\
\hline 100 & 375 & 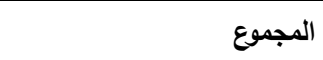 & \\
\hline 6,7 & 25 & ضعيف (11 - 21 درجة) & \multirow{4}{*}{ المشاركة في الأعمال التطوعية والخيرية بالقرية } \\
\hline 29,6 & 111 & متوسط (22 - 33 درجة) & \\
\hline 63,7 & 239 & مرتفع (34 - 44 درجة) & \\
\hline 100 & 375 & 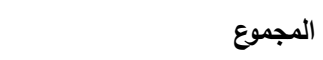 & \\
\hline 10,1 & 38 & ضعيف (10 - 19 درجة) & \multirow[t]{4}{*}{ الارتباط بمجتمع القرية } \\
\hline 38,2 & 143 & متوسط (20 - 30 درجة) & \\
\hline 51,7 & 194 & مرتفع (31 - 40 درجة) & \\
\hline 100 & 375 & المجموع & \\
\hline 13,3 & 50 & ضعيف (9 - 17 درجة) & \multirow[t]{4}{*}{ الاستعاد لتحمل المسئولية القيادية بالقرية } \\
\hline 58,7 & 220 & متوسط (18 - 27 درجة) & \\
\hline 28 & 105 & مرتفع (28 - 36 درجة) & \\
\hline 100 & 375 & 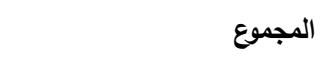 & \\
\hline 1,9 & 7 & ضعيف (68 - 135 درجة) & \multirow[t]{4}{*}{ إجمالي الانتماء للمجتمع المحلي } \\
\hline 66,6 & 250 & متوسط (136 - 204 درجة) & \\
\hline 31,5 & 118 & مرتفع (205 - 272 درجة) & \\
\hline 100 & 375 & 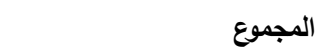 & \\
\hline
\end{tabular}


3- وجود علاقة ارتباطية عكسية ومعنوية عند المستوي

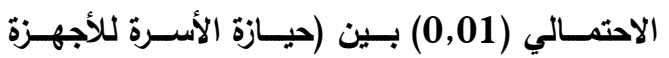
المنزلية، والتجديدية، وقضية الهجرة الخارجية) ويبين درجة الرضا عن الخدمات المحلية الموجودة بالقرية

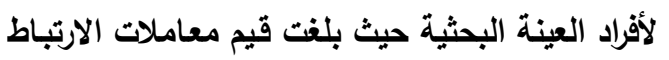
(0,142، -0,142، -0,154) علي الترتيب، كما

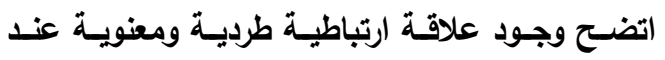

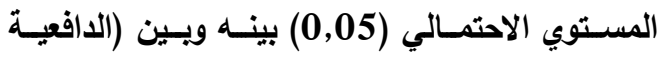
للإنجاز، وقضية استخذام وسائل التواصل الاجتماعي) حيث بلفت قيمة معامل الارتباط (0,128) علي الترتيب. 4- وجود علاقة ارتباطية طردية ومعنوية عند المستوي

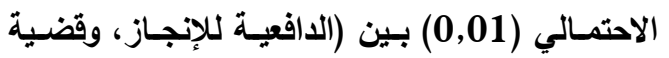

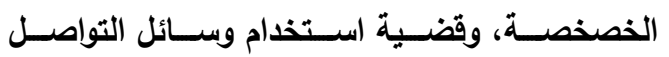

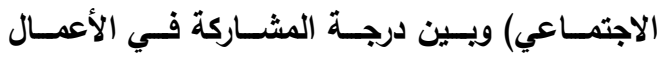

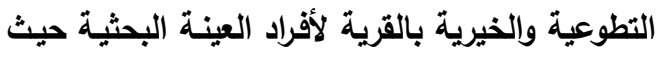

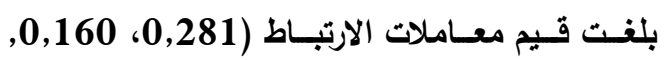

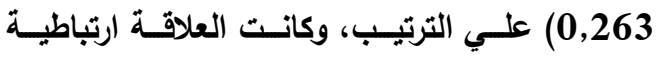
عكسية ومعنوية عند نفس المستوي الاحتمالي بينه

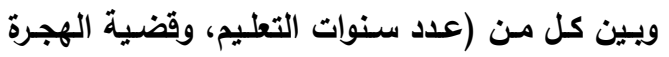

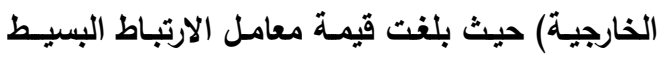

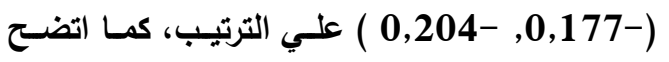
وجود علاقة ارتباطية طردية ومعنوية عند المستوي

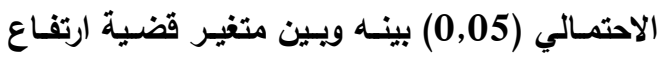

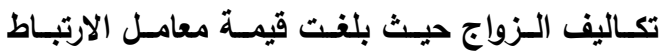

5- وجود علاقة ارتباطية طردية ومعنوية عند المستوي

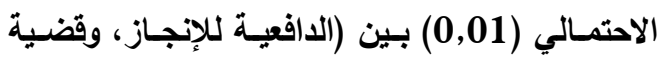

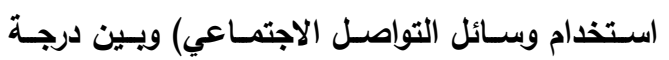

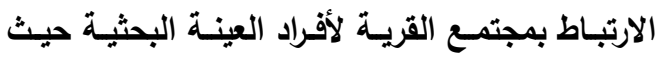

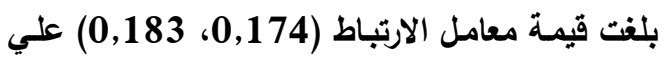
الترتيب، وكانت العلاقة ارتباطية عكسية ومعنوية عند

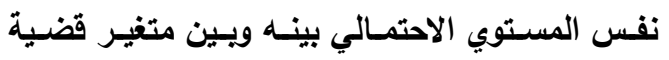

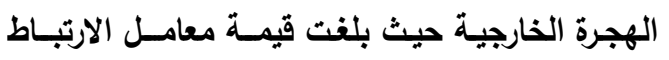
(0,301-)، كما اتضح وجود علاقة ارتباطية عكسية

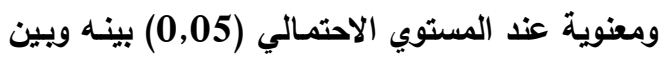

ثالثا: العلاقـات الارتباطيـة البسيطة بين المتغيرات

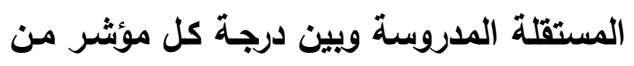

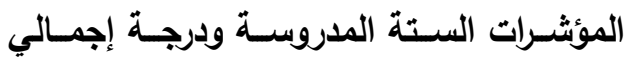
انتماء الثباب الريفي للمجتمع المحلي للتعـرف علـي العلاقـات الارتباطيـة البسـيطة بـين البـين المتغيرات المستقلة المدروسة ويين درجة كل مؤثر من العن

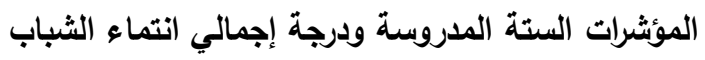
الريفي للمجتمع المحليتم صياغة الفرض البحثي الأول، المبل

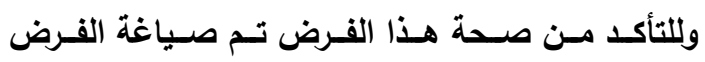
الإحصائي الصفري التالي: لا توجد علاقة التمبن ارتباطية بين

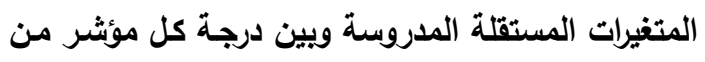

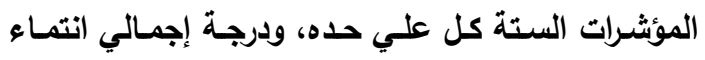

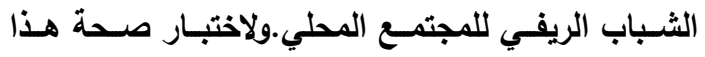
الفرض حسبت قيم معاملات الارتباط البسيط (بيرسون).

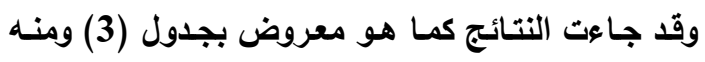
يتبين ما يلي: 1- وجود علاقة ارتباطية طردية ومعنوية عند المستوي الاحتمـالي (0,01) بين (الدافعيـة للإنجاز ، وقضسية

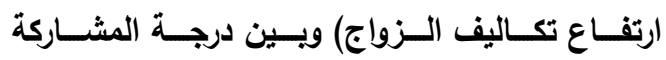
الاجتماعية غير الرسمية بالقرية لأفراد العينة البحثية حيث بلغت قيم معاملات الارتباط (0,271) 0,158) علي الترتيب، وكانت العلاقة ارتباطية عكسية ومعنوية

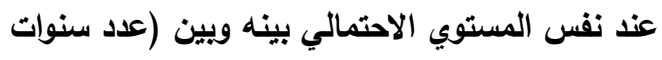

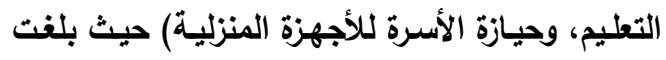

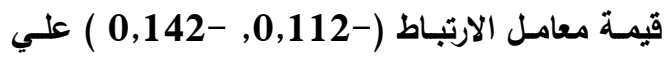
الترتيب، كمــا اتضـح وجـود علاقـة ارتباطيـة طرديـة

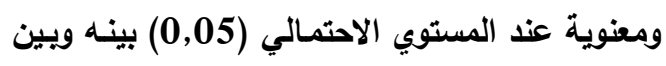
(قضية الخصخصة، وقضية استخدام وسائل التواصل

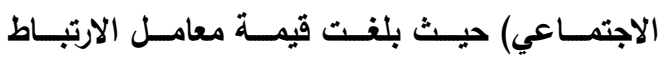

$$
\text { (0,110، 0,123) علي الترتيب. }
$$

2- وجود علاقة ارتباطية طردية ومعنوية عند المستوي

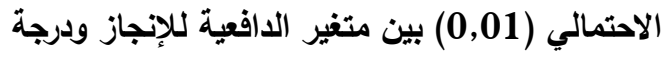
التمسك بالعادات والتقاليد السائدة بالقرية لأفراد العينة

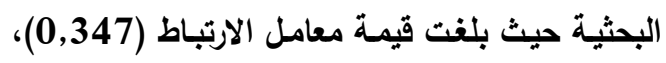

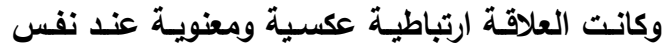

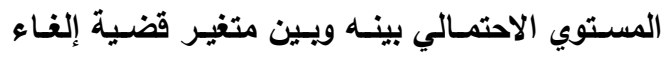

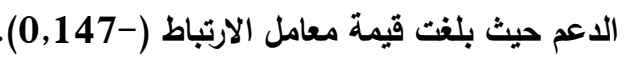


استخذام وسائل التواصل الاجتماعي) وبين درجة

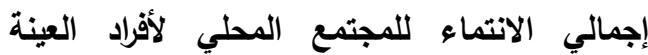
البحثية حيث بلغت قيمة معامل الارتباط (0,359، لألماءئ 0,246) علي الترتيب، وكانت العلاقة ارتباطية عكسية ومعنوية عند نفس المستوي الاحتمالي بينه

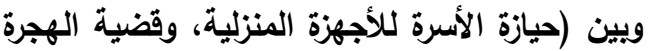

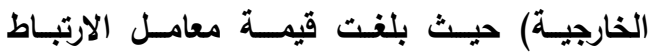

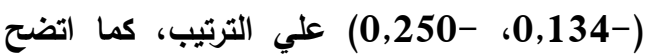
وجود علاقة ارتباطية عكسية ومعنوية عند المستوي كلفي

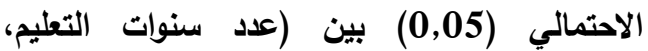

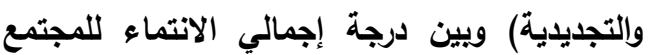
المحلي لأفراد العينة البحثية حيث بلفت قيمة البمائ معامل الارتباط (0,102، -0,130) علي الترتيب. (ويذلك يمكن رفض الفرض الإحصائي جزئيا وقبول

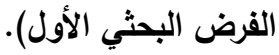

متغير حيازة الأسرة للأجهزة المنزلية حيث بلغت قيمة معامل الارتباط (-0,109). 6- وجود علاقة ارتباطية طردية ومعنوية عند المستوي

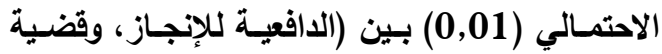

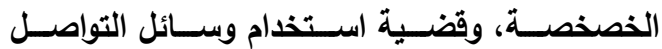
الاجتمـاعي) ويبين درجة الاستعداد لتحمل المسئولية

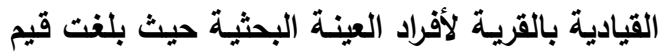
معاملات الارتباط (0,304، 0,143, 0,180$)$ الترتيب، كمـا اتضـح وجـود علاقـة ارتباطيـة طرديـة ومعنوية عذد المستوي الاحتمالي (0,05) بينه وبين

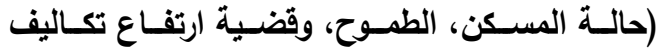
الزواج) حيث بلغت قيم معاملات الارتباط (0,124)، 0,108، 0,107) علي الترتيب. 7- وجود علاقة ارتباطية طردية ومعنوية عند المستوي الاحتمالي (0,01) بين (الدافعية للإنجاز، وقضية

جدول (3): قيم معاملات الارتباط البسيط (بيرسون) بين المتغيرات المستقلة المدروسة ويين درجة كل مؤثر من

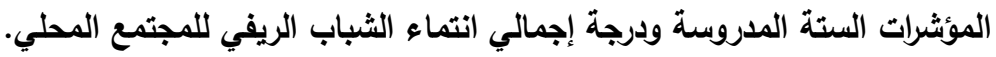

\begin{tabular}{|c|c|c|c|c|c|c|c|c|}
\hline الإنتماءي & التحمل التئولية القيادية & الارتباط & 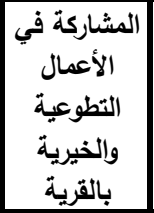 & الرالمات المداتة & بالتادات التماتك & 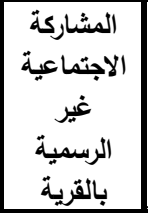 & الانتماء & \\
\hline 0,037 & 0,019 & 0,070 & 0,062 & $0,010^{-}$ & 0,090 & $0,072-$ & | - السن & 1 \\
\hline " $0,102-$ & $0,009-$ & $0,040^{-}$ & \%* $0,177-$ & $0,034-$ & $0,009-$ & $* 0,112$ & |عدد سنوات التعليم & 2 \\
\hline 0,031 & $0,019-$ & 0,065 & 0,040 & $0,008-$ & 0,031 & $0,001-$ & |حجم الأسرة & 3 \\
\hline 0,021 & 0,074 & $0,040^{-}$ & $0,057-$ & 0,091 & 0,023 & $0,006^{-}$ & | الدخل الشهري للأسرة & 4 \\
\hline 0,035 & $* 0,124$ & 0,000 & 0,008 & 0,006 & $0,040^{-}$ & 0,048 & |حالة المسكن & 5 \\
\hline$\div * 0,134-$ & 0,071 & *0,109- & $0,070-$ & $* * 0,142-$ & $0,035-$ & $* 0,142-$ & |حيازة الأسرة للأجهزة المنزلية & 6 \\
\hline 0,064 & ${ }^{*} 0,108$ & 0,046 & 0,101 & $0,018-$ & 0,058 & $0,013-$ & |لطموح & 7 \\
\hline${ }^{*} 0,130-$ & 0,021 & $0,097-$ & $0,068-$ & $\because * 0,142-$ & $0,038-$ & $0,086-$ & | التجديدية & 8 \\
\hline$* * \mathbf{0 , 3 5 9}$ & $* * 0,304$ & $* * 0,174$ & $* * 0,281$ & $* 0,128$ & $* * 0,347$ & $* * 0,271$ & |الدافعية للانجاز & 9 \\
\hline 0,095 & *** 0,143 & 0,040 & ***0,160 & $0,041-$ & 0,036 & $* 0,110$ & قضية الخصخصة & 10 \\
\hline 0,005 & 0,086 & $0,031-$ & 0,007 & 0,003 & ***0,147- & 0,074 & قضية إلغاء الدعم & 11 \\
\hline 0,69 & *0,107 & $0,21-$ & *0,121 & $0,020-$ & $0,020^{-}$ & $* * 0,158$ & قضية ارتفاع تكاليف الزواج & 12 \\
\hline ***0,246 & *** 0,180 & $* * 0,183$ & $* * 0,263$ & ${ }^{*} 0,115$ & 0,022 & *0,123 & 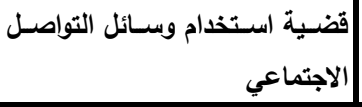 & 13 \\
\hline$\% * 0,250-$ & $0,052-$ & $* * 0,301-$ & $* 0,204-$ & $* * 0,154-$ & $0,064-$ & $0,071-$ & قصية الهجرة الخارجية & 14 \\
\hline
\end{tabular}


0.01، وهذا يفيد بأن هناك متغيرين مستقلينيفسران

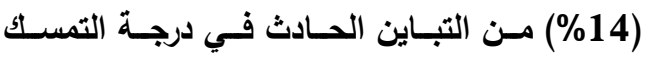

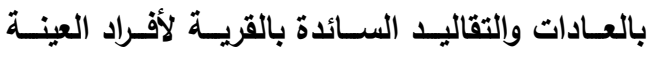
البحثية، وأن هذين المتغيرين يسهمان إسهاماً معنوياً فريدا في تفسير التباين علي النحو التالي: الدافعية التئية للإنجاز (12,1\%)، و قضية إلغاء الاعم (1,9\%).

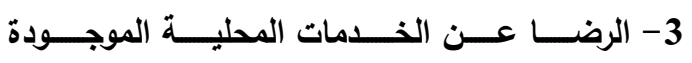

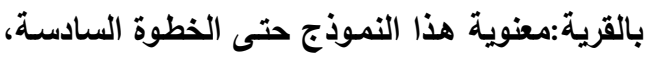
حيث بلغت قيمة معامل الارتباط المتعدد (0,328)

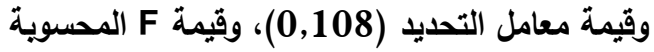

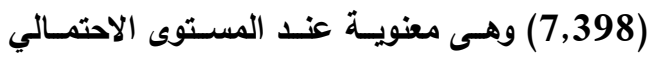
0.01، وهذا يفيد بأن هناك ستة متغيرات مستقلة تفسر (10,8\%) في التباين الحادث في درجة الرضاك

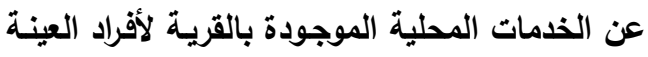
البحثيـة، وأن هذه المتغيـرات تسـهم إسـهاماً معنويـاً فريدا في تفسير التباين علي النحو التالي:قضية التهاية

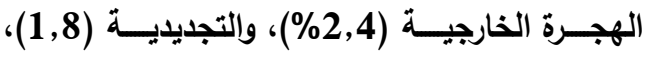

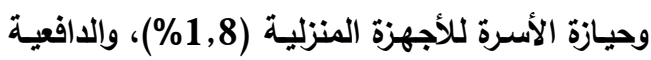

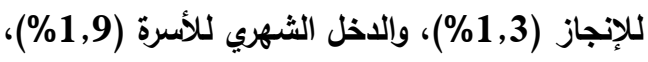

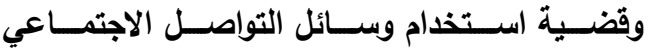
. 1 1,2)

4- المشاركة في الأعمال التطوعية والخيرية:معنوية هذا النمـوذج حتى الخطوة السادسة، حيث بلغت قيمـة

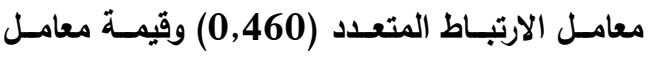

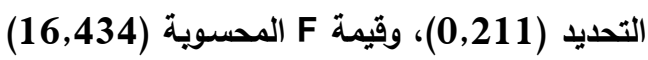
وهى معنويـة عند المستوى الاحتمالي 0.01)، وهذا يفيد بأن هناك ستةمتغيرات مستقلة تفسر (21,1\% في التباين الحادث في درجة المشاركة في الأعمال

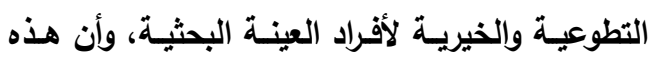

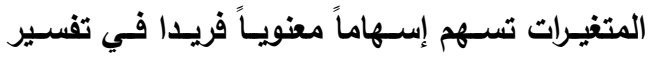
التبـاين علــي النـــو التـالي: الدافعيـة للإنجـاز

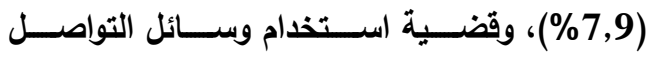
الاجتماعي (5,7\%)، وقضية ارتفاع تكاليف الزواج

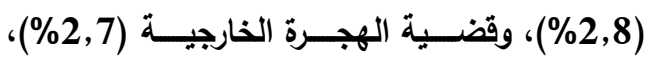

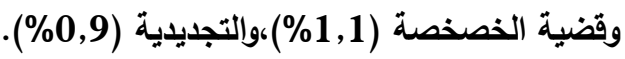

رابعاً: الإسهام النسبي للمتغيرات المستقلة المدروسة في تفسير التباين الحادث في درجة كل مؤشثر الإنئ من المؤشرات الستة المدروسة واجمالي انتماء الثباب الريفي للمجتمع المحلي لتحديد الإسهام النسبي للمتغيرات المستقلة المدروسة

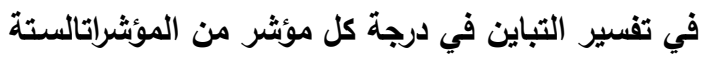

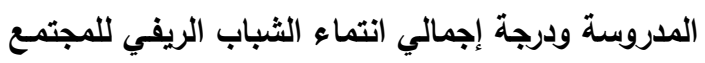

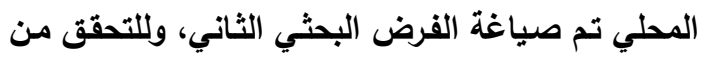
صحة هذا الفرض تم صياغة الفرض الإحصائي الصفري

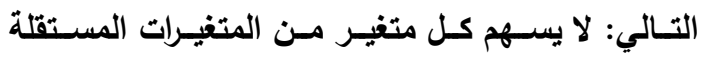

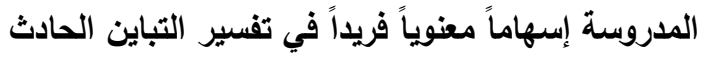

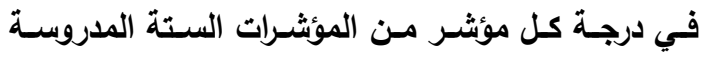

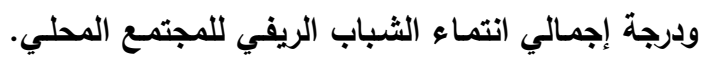
ولاختبار صحة هذا الفرض تم استخدام تحليل الاتحدار

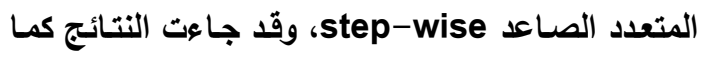
هو معروض بجدول ( 4 ) ومنه يتبين ما يلي: 1-المشـاركة الاجتماعية غير الرسمية بالقريـة: معنويـة

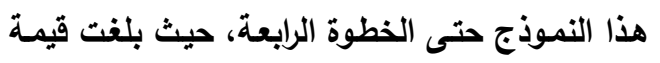

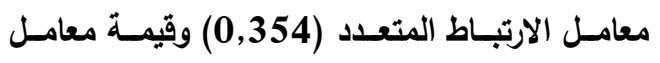

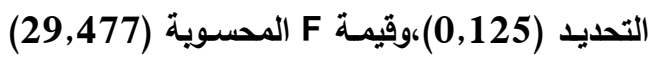

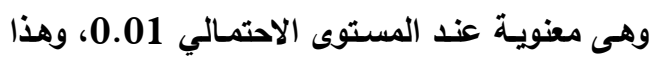

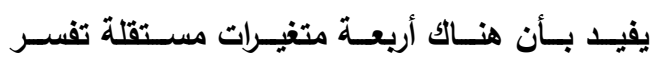
الاجيماعـا (12,5) في التباين الحادث في درجة المشـاركة

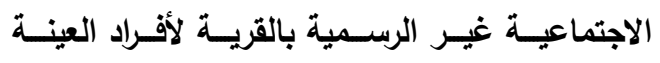

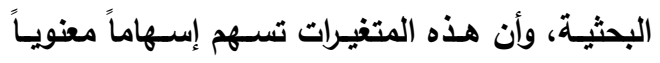
فريدا في تفسير التباين علي النحو التالي: الدافعية

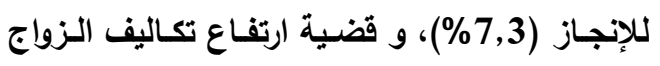

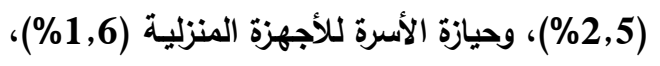
وقضية الهجرة الخارجية (1,1,1\%).

2- التمسك بالعادات والتقاليد السـائدة بالقريـة: معنويـة

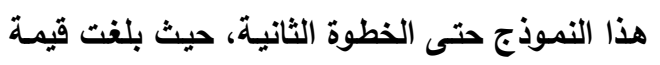

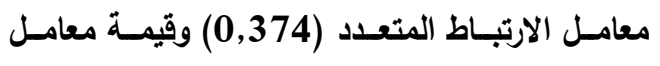

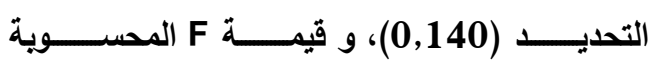
(30,262) وهـى معنويـة عند المستوى الاحتمـالي 
جدول (4): الأهمية النسبية للمتغيرات المستقلة المؤثرة في تفسير التباين الحادث في درجة كل مؤثر من المؤشرات الستة المدروسة واجمالي انتماء الثباب الريفي للمجتمع المحلي.

\begin{tabular}{|c|c|c|c|c|c|c|}
\hline $\begin{array}{c}\text { F } \\
\text { لاختبار المعنوية }\end{array}$ & 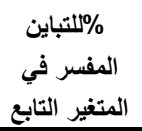 & $\begin{array}{c}\text { معامل التحديد } \\
\text { R2 }\end{array}$ & 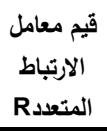 & المتغيرات المؤثرة & خطوات التحليل & الانتماء للمجتمع \\
\hline$* * 29,477$ & 7,3 & 0,073 & 0,271 & | الدافعية للإنجاز & الخطوة الأولى & \multirow{4}{*}{ الاجتماعية غير المشاركة } \\
\hline$* * 20,210$ & 2,5 & 0,098 & 0,313 & قضية ارتفاع تكاليف الزواج & الخطوة الثانية & \\
\hline$* * 15,880$ & 1,6 & 0,114 & 0,337 & | حيازة الأسرة للأجهزة المنزلية & 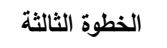 & \\
\hline$* * 13,250$ & 1,1 & 0,125 & 0,354 & قضية الهجرة الخارجية & 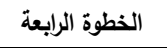 & \\
\hline$* * 51,142$ & 12,1 & 0,121 & $\mathbf{0 , 3 4 7}$ & | الدافعية للإنجاز & 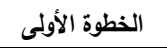 & \multirow{2}{*}{ 2- الباداد التمكك } \\
\hline$* * 30,262$ & 1,9 & 0,140 & 0,374 & قضية إلغاء الدعم & 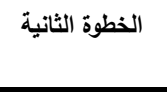 & \\
\hline$* * 9,089$ & 2,4 & 0,024 & 0,154 & قضية الهجرة الخارجية & الخطوة الأولى & \multirow{6}{*}{ 3- الذدمات المحلية } \\
\hline$* * 8,915$ & 2,2 & 0,046 & 0,214 & التجايدية & الخطوة الثانية & \\
\hline$* * 8,480$ & 1,8 & 0,064 & 0,253 & حيازة الأسرة للأجهزة المنزلية & 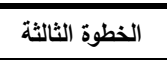 & \\
\hline$* * 7,680$ & 1,3 & 0,077 & 0,277 & الدافعية للإنجاز & الخطوة الرابعة & \\
\hline *** 7,801 & 1,9 & 0,096 & 0,309 & الاخل الشهري للأسرة & الخطوة الخامسة & \\
\hline$* * 7,398$ & 1,2 & 0,108 & 0,328 & قضية استخدام وسائل التواصل الاجتماعي & الخطوة السادسة & \\
\hline **31,882 & 7,9 & 0,079 & 0,281 & الدافعية للإنجاز & الخطوة الأولى & \multirow{6}{*}{ الأعمال التطوعية النشية في } \\
\hline$* * 29,272$ & 5,7 & 0,136 & 0,369 & قضية استخدام وسائل التواصل الاجتماعي & الخطوة الثانية & \\
\hline$* * 24,318$ & 2,8 & 0,164 & 0,405 & قضية ارتفاع تكاليف الزواج & الخطوة الثالثة & \\
\hline$* * 21,902$ & 2,7 & 0,191 & 0,438 & قضية الهجرة الخارجية & الخطوة الزرابعة & \\
\hline$* * 18,649$ & 1,1 & 0,202 & 0,449 & قضية الخصخصة & الخطوة الخامسة & \\
\hline$* * 16,434$ & 0,9 & 0,211 & 0,460 & التجديدية & الخطوة السادسة & \\
\hline$* * 37,270$ & 9,1 & 0,091 & 0,301 & قضية الهجرة الخارجية & الخطوة الأولى & \multirow{4}{*}{ 5 5- الارتباط } \\
\hline$* * 25,234$ & 2,8 & 0,119 & 0,346 & الدافعية للإنجاز & 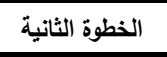 & \\
\hline$* * 19,487$ & 1,7 & 0,136 & 0,369 & قضية استخدام وسائل التواصل الاجتماعي & الخطوة الثالثة & \\
\hline$* * 16,655$ & 1,7 & 0,153 & 0,391 & التجايدية & الخطوة الرابعة & \\
\hline$* * 37,886$ & 9,2 & 0,092 & 0,304 & الدافعية للإنجاز & الخطوة الأولى & \multirow{4}{*}{ 6- 6- الاستعداد } \\
\hline$* * 24,394$ & 2,4 & 0,116 & 0,341 & قضية استخدام وسائل التواصل الاجتماعي & الخطوة الثانية & \\
\hline$* * 17,840$ & 1 & 0,126 & 0,355 & حالة المسكن & الخطوة الثالثة الثة & \\
\hline$* * 14,503$ & 1 & 0,136 & 0,368 & قضية ارتفاع تكاليف الزواج & الخطوة الزرابعة & \\
\hline$* * 55,361$ & 12,9 & 0,129 & 0,359 & الدافعية للإنجاز & الخطوة الأولى & \multirow{5}{*}{ 7- الانتماء للمجتمع } \\
\hline$* * 43,367$ & 6 & 0,189 & 0,435 & قضية الهجرة الخارجية & الخطوة الثانية & \\
\hline$* * 35,524$ & 3,4 & 0,223 & 0,472 & قضية استخام وسائل التواصل الاجتماعي & 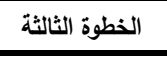 & \\
\hline$* * 31,500$ & 3,1 & 0,254 & 0,504 & والتجديدية & الخطوة الرابعة & \\
\hline$* * 27,018$ & 1,4 & 0,268 & 0,518 & قضية ارتفاع تكاليف الزواج & الخطوة الخامسة & \\
\hline
\end{tabular}

جمعت وحسبت من بيانات الاراسة * * مغنوي عند 0,01 
هذه المتغيرات تسهم إسهاماً معنوياً فريدا في تفسير التبـاين علــي النــــو التــالي: الدافعيـة للإنجــاز (12,9\%)، وقضية الهجرة الخارجية (6\%)، وقضية

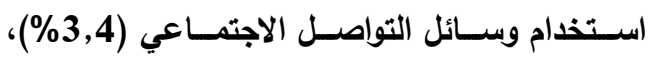
والتجديدية (3,1\%)، و قضية ارتفاع تكاليف الزواج (و,4\%). (ويـلكك يمكن رفض الفـرض الإحصـائي جزئيا وقبول الفرض البحثي الثاني). مناقشة النتائج 1- تبين وجـود علاقـة ارتباطيـة طرديـة ومغنويسة عند المستوي الاحتمـالي (0,01) بين كل مسن الدافعيـة للإنجاز، وقضية استخذام وسائل التواصل الاجتماعي

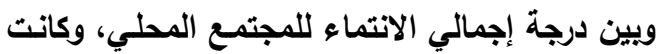

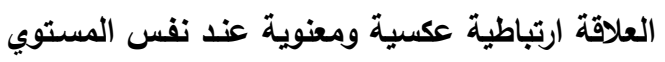
الاحتمـالي بينهـه ويبين كل من حيـازة الأسرة للأجهزة المنزلية، وقضية الهجرة الخارجية، كما اتضح وجود

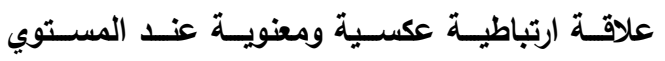
الاحتمالي (0,05) بين كل من عدد سنوات التبات التعليم،

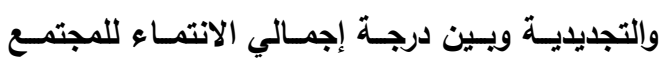
المحلي.

2- اتضح أن أكثر المتغيرات إسهاماً في تفسير التباين الحسادث في إجمـالي الانتمـاء للمجتمـع المحليمرتبـة المئة حسب أهميتها هي: الدافعية للإنجاز، وقضية الهجرة الأبئية

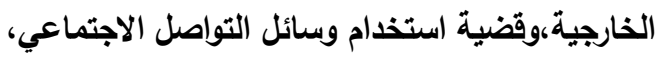
والتجديديـة، وقضـية ارتفـاع تكـاليف الزواج، وتفسر نحو (26,8\%) من التباين الحادث.

وفي ضـوء نتـائج الدراسـة تبين أن انتمـاء الثـباب الريفي للمجتمـع المحلـي يزداد بزيـادة الدافعيـة للانجـاز

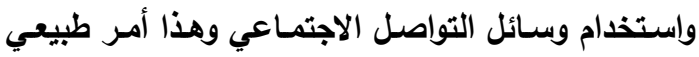
ويتفق مـع الواقع الفعلي حيث أن استعداد الفرد لانجاز

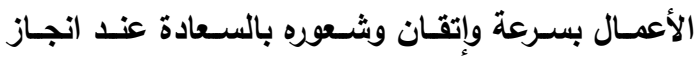
الأعمـال الصسعبة والاستفادة مـن الإمكانيـات المتعـدادة

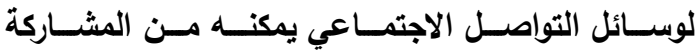

5-الارتباط بمجتمـع القريـة: معنويـة هذا النمـوذج حتى

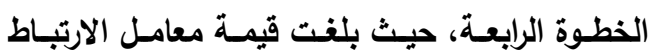

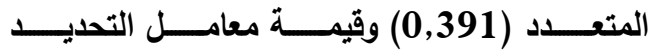

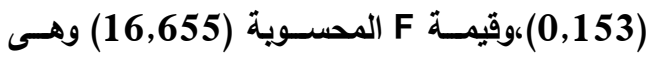
معنويـة عند المستوى الاحتمـالي 0.01، وهذا يفيد بأن هناك أربعة متغيرات مستقلة تفسر (15,3)

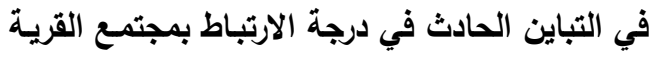

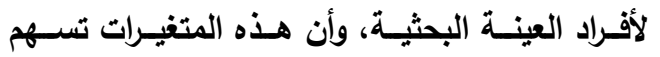

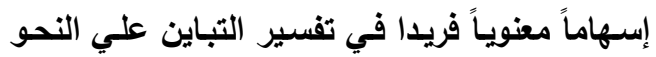

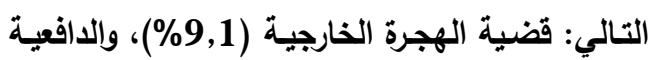
للإنجاز (2,8\%)، وقضية استخدام وسـائل التواصل الاجتماعي (1,7\%)، والتجديدية (1,7\%)، وفئة (1,8).

6-الاستعداد لتحمل المسئولية القيادية بالقرية: معنوية هذا النموذج حتى الخطوة الرابعة، حيث بلغت قيمة لئهة

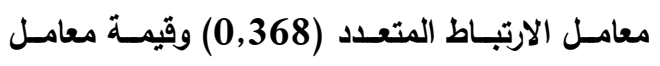

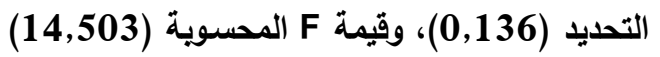
وهى معنويـة عند المستوى الاحتمـالي 0.01، وهذا وفئه

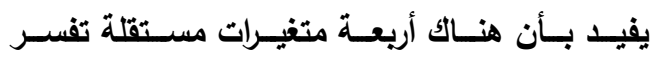
(\% 13,6) في التباين الحسادث في درجة الاستعداد

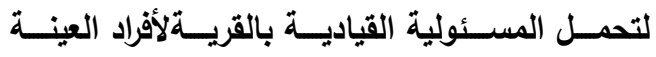
البحثيـة، وأن هذه المتغيرات تسـهم إسـهاماً معنويـاً

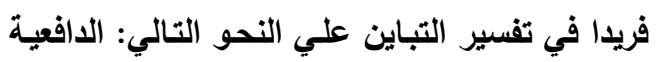
للإنجاز (9,2\%), وقضية استخدام وسائل التواصل

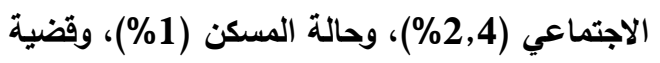
ارتفاع تكاليف الزواج (1\%).

7-إجمـالي الانتمــاء للمجتــع المحــي: معنويـة هـــا

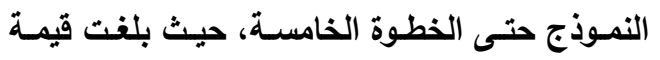
معامسل الارتبـاط المتعـد (0,518) وقيمــة معامـل

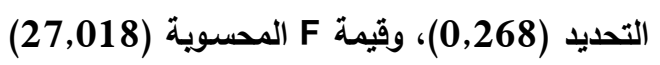

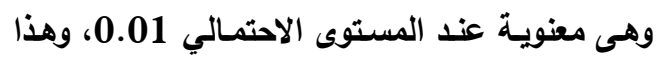

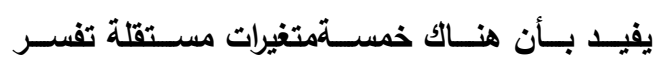
(26,8\%) في التبـاين الحسادث في درجـة إجمـالي الانتمـاء للمجتمع المحلي لأفراد العينة البحثية، وأن البه 
المراجع:

1- أسـتيتية، دلال محسـن ، وعمسر موسـي سـرحان:

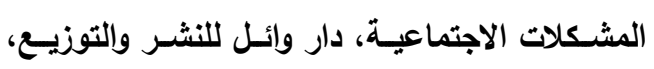

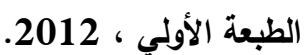

2- أبو المعاطي، وليد محمد ، ومنـار منصسور أحمد:

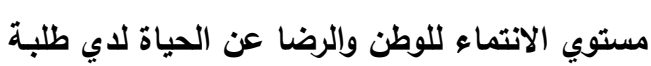

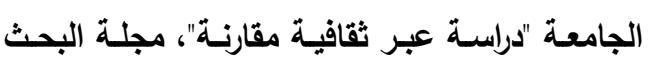
العلمسي في التربيـة ، كليـة البنـات لـلآداب والعلـوم

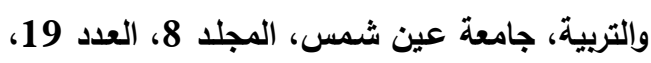
.2018

3-الخضــيري، صـالح إبـراهيم: الثـبكات الاجتماعيـة المهاجرة ودورها في عملية الهجرة الخارجية، "دراسـة

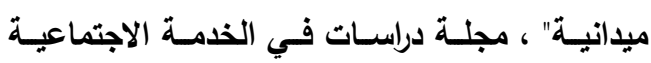

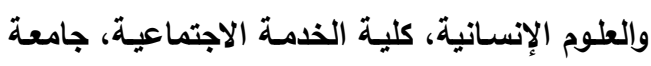
حلوان، المجلد 1، العدد 26، إبريل ، 2009. 4- الرفـاعي، سـليمان حسن سليمان: العوامـل المـؤئرة

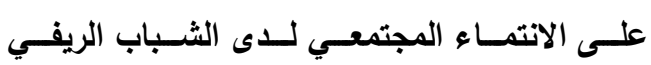

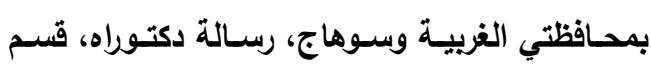

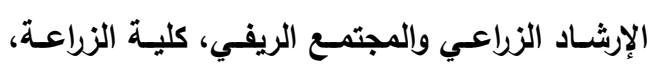

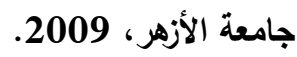

5- الريدي، جمال حسين: دراسة لبعض العزئ والعامل المؤثثرة

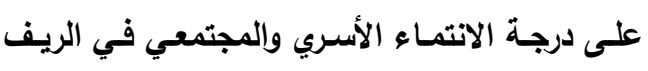
"دراسـة ميدانيـة في ريف محافظة المنيا"، المؤيتمر

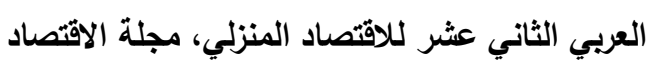

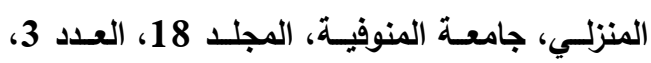
أغسطس ، 2008.

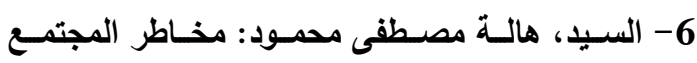

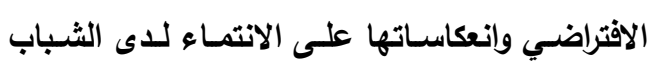

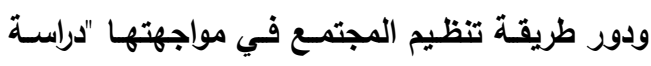

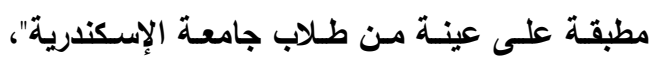

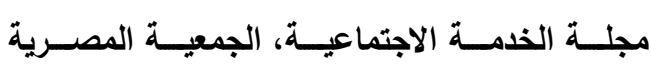

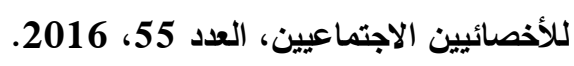
7- الصرابي، يحي على حسين: الانتماء واللولاء للوطن اللمني وأهميتهـ، شـئون العصـر، المركز اليمنـي للاراســات
الاجتماعية والتطوعية والخيرية ويجطله قادر علي القيام

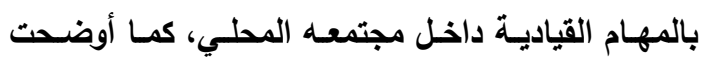
النتائج أن الانتماء للمجتمع المحلي يقل بزيادة التجديدية

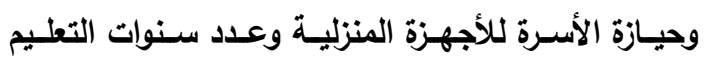

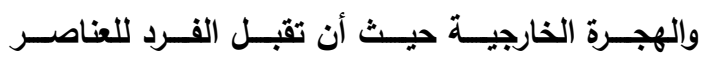

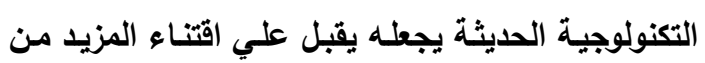

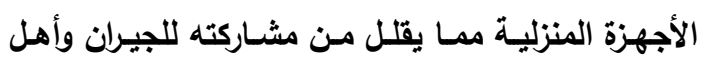

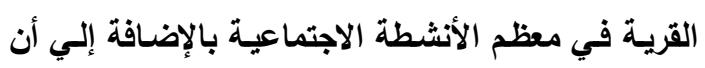
زيـادة تعليم الفرد يقلـل مسن تمسكه بالعـادات والتقاليـل

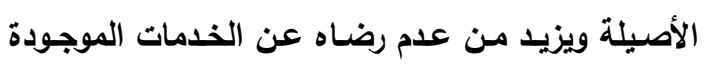
بالقرية مما يدفع الثباب لعدم الارتباط بمجتمعه المحلي

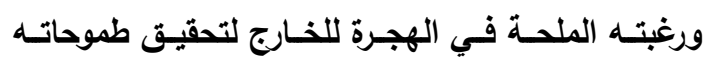

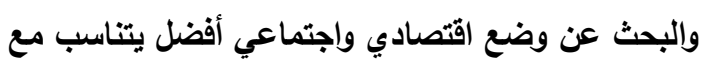
مؤهله العلمي ورغباته الملحة.

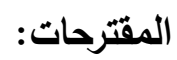
في ضوء النتائج السابقة تقترح الدراسة ما يلي:

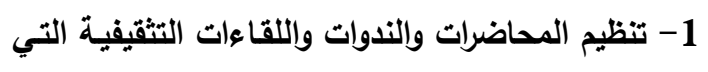
تحث الشباب علي أهمية التمسك بالعادات والتقاليد

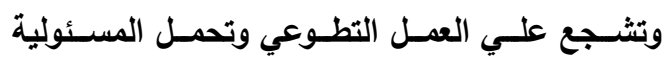
القيادية بالمجتمع. 2- ضرورة اهتمام المؤسسات المغنية في القريـة كمراكز

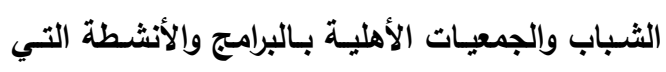
تساعد علي تنمية روح الانتماء للمجتمع المحلي لدي الشباب مثل برامج خدمة المجتمع وتنميته. 3- التأكيد علي دور الأسرة ومساندة المدرسة والجامعة ولتئه

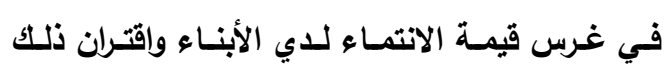

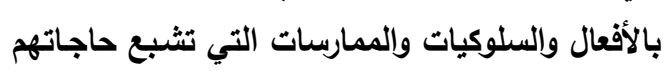
للانتمـاء وتنمسي فيهم روح العطاء وتثـعرهم بـالفخر والارتباط بالمجتمع.

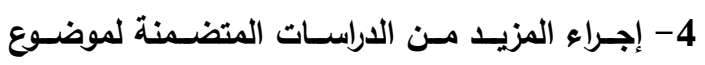

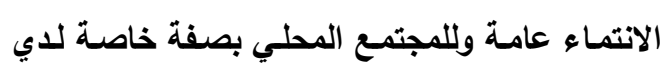
الشباب الريفي وعلـي الأخص الثباب الريفي لندرة

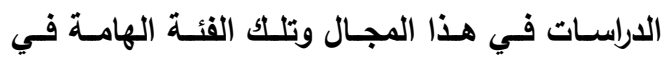


16- عوض، شريف محمد: أثر ارتفاع تكاليف الزواج في تأخر سن الزواج "دراسة اجتماعية لاقتصاديات

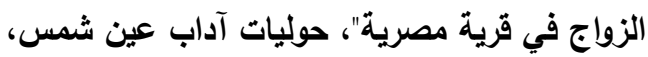

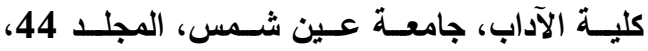
مارس، 2016.

17- فههي، محمد سيد: العمل مـع جماعات الثباب ودعم الانتماء الوطني في ظل العولمة "دراسة مطبقة علي مركز شباب نصر بالإسكندرية"، مجلة دراسات

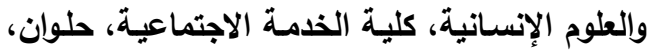
العدد العاشر، إبريل، 2001.

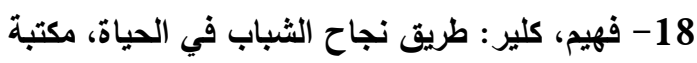
الانجلو المصرية، القاهرة، الطبعة الأولي، 19 - قتيير ، خالد عبد الفتاح على: الهجرة غير الثرعية للشباب الريفي " دراسة على عينة من شباب محافظة المنوفية بايطاليا "، مجلة المنوفية للبحوث الزراعية لئية

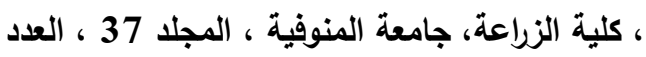

2، إبريل ، 2012

20- محمـد، سـليم شـعبان سـليمان: التخطيط لــــمم

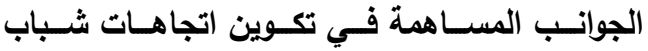
الجامعة نحو العمل بالقطاع الخاص، مجلة دراسـات

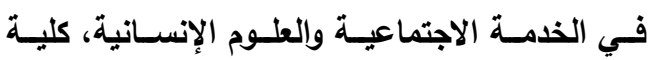
الخدمـة الاجتماعيـة، جامعـة حــوان، الجـزء الأول،

$$
\text { العدد السادس عشر، ابريل، } 2004 .
$$

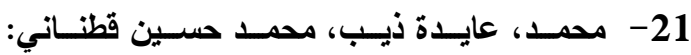
الانتماء والقيادة والشخصية لدى الأطفال الموهوبين والعاديين، دار جرير للنشر والتوزيع، الطبعة الأولى،

22 - مكروم، عبد الـودود: القيم ومسئوليات المواطنـة "روئية مستقبلية"، دار الفكر العربي، الطبعة الأولي، .2004

23 - يوســف، محمـــ محمـود عطــوة: تحليـل الآثـار

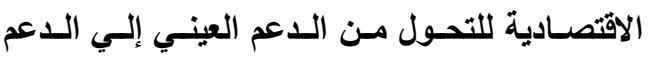

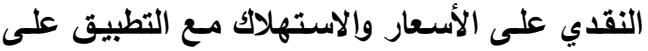

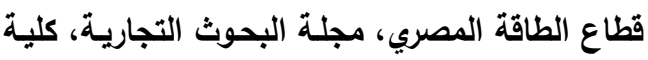
التجارة، جامعة الزقازيق، المجلد الثاني والثثلاثون،

$$
\text { العدد الثاني، يوليو ، } 2010 .
$$

الإســتراتيجية، المجلـــ 18، العـدلد 51، أكتـوير ديسمبر، 8- العرجا، ناهدة سـابا، وتيسير محمد عبد الله: الأمن النفسي وعلاقته بالانتماء الوطني لدى قوات الأمن الـوطني الفلسطيني في منطقة بيـت لحم، المجلـة

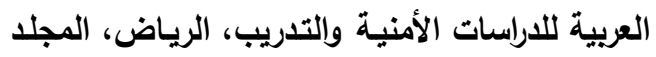
31 31، العدد 62، 2015. - 32. 9- العثـري، ولاء عبــ المــعم عبـــ المــعم: وســائل التواصل الاجتمـاعي عبر شبكة الانترنت وعلاقتها

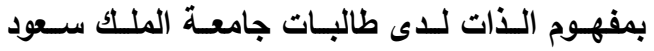

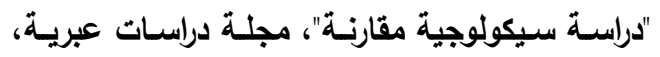
رابطة الأخصائيين النفسيين المصرية، المجلد 13، العدد 1، 2014. 10- خضـر، لطيفـة إبـراهيم: دور التعلـيم فـي تعزيـز

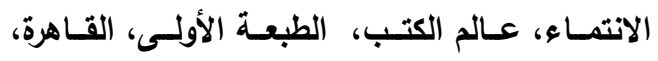
مارس ، 2000. 11-درويش، محمد أحمد: العولمـة والمواطنة والانتماء الــوطني، عــالم الكتـب، الطبعـة الأولـــ، القــاهرة، .2009

12- زكى، أمل محمد: هجرة الثباب وقضايا الانتمـاء للمجتمـع "دراسـة ميدانيـة لواقع الثباب المصري في مئي

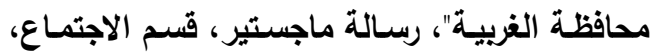
كلية الآداب، جامعة طنطا، 2016. 13- سليمان، سناء محمد: سيكولوجية الحب والانتماء، الاعه، طنط، عالم الكتب، الطبعة الأولى، القاهرة، 2013. 14- شـــحان، شــهاب محمــا: إثـكالية الخصخصــة

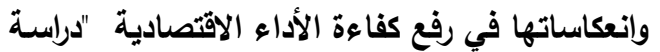
تحليليـة تطبيقيـة"، مجلـة جامعـة الأنبـار للعــوم

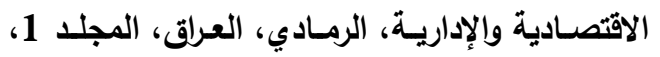
العدد 2، 2008.

15- عــرب، أروي حســـي: المســـولية الاجتماعيــة وعلاقتها بالانتماء الوطني والأمن الفكري لدي عينة من طالبـات ومنسويات جامعة الملك عبد العزيز، المجلة العلمية، كلية التربية، جامعة أسيوط، المجلد 34، العدد 2، جزء ثاني، فبراير، 2018. 


\title{
THE RELATIONSHIP BETWEEN SOME CONTEMPORARY ISSUES AND THE RURAL YOUTH FILLIATION TO THE COMMUNITY IN EL- GHARBIA GOVERNORATE
}

\author{
Laila M. M. Al-khalwany, Abeer A. M. Allam and Huda M. I. Al-Laithi \\ Department of Rural Family Development - Faculty of Home Economics, \\ Tanta , Al-Azhar University, Egypt.
}

\begin{abstract}
This research mainly aims to investigate the nature of the relationship between some contemporary issues and rural youth filiation to the community in ElGharbia Governorate, through achieving the following sub-goals:- Identifying the level of rural youth filiation to the community with its six studied indicators, namely (the informal social participation in the village, the adherence to the customs, traditions and the prevailing values in the village, their satisfaction with the local services in the village, their participation in volunteer and charitable affairs in the village, the correlation with the village community and their preparedness to assume the responsibility of leadership of the village), and recognition of the correlational relationships between the independent studied variables and the degree of each indicator of the rural youth filiation to the local community separately and the degree of total filiation to the local community, and determining the regressive relationships between the studied independent variables and the degree of each indicator of the filiation of the rural youth to the community separately and the degree of total filiation to the local community. The research was conducted on a random sample consisting of 375 youth ranged from (20) to (35) years from three villages chosen for the study, namely (Fisha Selim, Kharsit, Kafr Sabtas). The research data were collected through a personal interview using a questionnaire form. Several descriptive and statistical methods were used to analyze the data such as Alpha coefficient, frequencies, percentages, arithmetic mean, standard deviation, simple correlation coefficient (Pearson), multiple correlation coefficient and standard partial regression coefficient. The most important results of the research were summarized as follows: The level of adherence to the customs, traditions and the prevailing values in the village, participation in voluntary and charitable affairs in the village, and correlation with the village community was high $(71.2 \%),(63.7 \%),(51.7 \%)$ respectively, the informal social participation in the village was between medium and high $(98.7 \%)$, and the total filiation to the community, and the preparedness to assume the responsibility of leadership of the village was medium $(66.6 \%)$ and $(58.7 \%)$ respectively. The level of satisfaction of the local services is close in the three categories. It also found that there is an extreme and moral correlational relationship between the motivation to achieve and the issue of using social media and the degree of total filiation to the local community, and the relationship was inverse and moral between it and the number of educational years, the family possession of household appliances, renewal, and the issue of immigration abroad. It also showed that the most important variables participating in indicating the variance occurred are: the motivation for achievement, the issue of immigration abroad, the issue of using social media, renewal, and the issue of increasing the marriage costs, and it indicate $(26.8 \%)$ of the variance occurred. The most important recommendations of the research are, emphasize the role of the family and support the school and university to instill the value of filiation in children, and conduct more studies of the issue of filiation in general and especially for the community among youth in general and rural youth in particular.
\end{abstract}

Key words: Youth, filiation, Privatization, subsidy, costs of marriage, foreign immigration, social media.

$$
\begin{aligned}
& \text { سماء السادة المحكمين } \\
& \text { أ.د/ وفاء أحمد أبوحليمه كلية الأقتصاد المنزلى - جامعة الأزهر }
\end{aligned}
$$

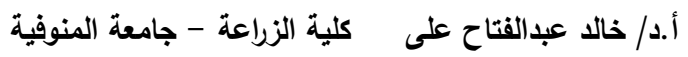

